\title{
Asset Management as a Digital Platform Industry: A Global Financial Network Perspective
}

\author{
Daniel Haberly ${ }^{\mathrm{a}, *}$, Duncan MacDonald-Korth ${ }^{\mathrm{b}}$, Michael Urban ${ }^{\mathrm{b}}$, Dariusz Wójcik ${ }^{\mathrm{b}}$ \\ ${ }^{a}$ University of Sussex, School of Global Studies, Department of Geography, United Kingdom \\ ${ }^{\mathrm{b}}$ University of Oxford, School of Geography and the Environment, United Kingdom
}

\section{A R T I C L E I N F O}

\section{Keywords:}

Asset management

Digital platform economy

Fintech

Global Financial Networks

BlackRock

\begin{abstract}
A B S T R A C T
While contemporary technological disruption is increasingly conceptualized in terms of the logic and paradoxes of the digital platform economy, discussions of "FinTech" have only engaged to a limited extent with these debates-particularly from an economic geographic standpoint. Here we fill this gap by proposing an adapted Global Financial Network (GFN) framework for conceptualizing the organizational and geographic logic of the digital platform economy in finance, and applying it to examine the impact of the digital platform model on asset management. As we will show, asset management is being profoundly disrupted by what we dub digital asset management platforms-or DAMPs - which encompass services including index fund and ETF provision, roboadvising, and analytics and trading support. Like other digital platforms, DAMPs do not so much leverage technology to enhance their competitiveness within markets, as to radically restructure the market itself. Also, like other platforms, their rise has produced a winner-take-all paradox of centralization through democratization that defies predictions of technology-enabled industry decentralization. However, the logic and implications of the rise of DAMPs diverges, in other respects, from non-financial digital platforms, as finance has long possessed an informational intensity and regulatory and organizational fluidity characteristic of the digital platform economy. Consequently, the digital platform model has mostly developed endogenously in asset management through incremental innovation by major financial firms-in a process that has reinforced the position of leading incumbent asset management centers, and above all New York-rather than being introduced from the outside by upstart technology firms and clusters.
\end{abstract}

"[BlackRock's Aladdin] has within its memory a vast history of the past 50 years - not just financial - but all kinds of events. What it does is constantly take things that happen in the present day and compares them to events in the past. Out of the millions and millions of correlations Aladdin then spots possible disasters - possible futures - and moves the investments to avoid that future happening. I can't over-emphasise how powerful Blackrock's system is in shaping the world - it's more powerful in some respects than traditional politics...But it's boring. And there is no story. Just patterns...It is the modern world of power - and it's incredibly boring. Nothing to film, run by a cautious man who is in no way a wolf of Wall Street. It's how power works today. It hides in plain sight - through sheer boringness and dullness." - Adam Curtis

\section{Introduction}

From the invention of writing, to Nathan Rothschild's apocryphal carrier pigeons, the financial sector has always been a precocious adopter of information and communications technology. In 1837, one French deputy declared that "I have never seen telegraphic lines established by private persons with good intentions'; they serve to 'establish a brigandage, so as to rob those who do not have news of the Paris Bourse" (Flichy, 1993). However, there is a growing sense of a new era of technological disruption in finance, with two narratives now particularly prominent. The first is disruptive automation; one study suggests that $23 \%$ of financial analyst, and $58 \%$ of financial advisor jobs may be lost in the near future (Frey and Osborne, 2017). The second is disruptive decentralization, with three notable subcomponents. Firstly, at the firm level, incumbent giants are expected to be brought down by swarms of innovative "FinTech" start-ups (Arner et al., 2016). Meanwhile, geographically, incumbent financial centers (e.g. Wall Street) will be hollowed-out by competition with upstart, tech-savvy locales (Tett, 2018). Finally, with respect to governance, regulators will be outflanked by the institutions of "Web 3.0"-e.g. decentralized blockchain ledgers (Economist, 2018a; Swan, 2015).

\footnotetext{
* Corresponding author at: Arts C, University of Sussex, Falmer, Brighton BN1 9SJ, United Kingdom.

E-mail address: d.haberly@sussex.ac.uk (D. Haberly).
} 
In general, these narratives are uncannily reminiscent of the utopian (or dystopian) predictions of the early days of the internet; or in the case of automation, more longstanding predictions about the obsolescence of work. As noted by the Economist (2018b), the internet has not only failed to bear out early predictions of a decentralized, libertarian "flat world," but has largely led to the opposite outcome, wherein a growing number of industries are controlled by massive monopolistic firms, which are based in a handful of elite locations, serve as agents of unprecedentedly pervasive regimes of state surveillance and control, and have catalyzed an explosion of low-paid menial work in the "gig" economy.

At the center of this paradox is a business model dubbed the "digital platform economy" (Kenney and Zysman, 2016; Evans and Gawer, 2016; Langley and Leyshon, 2017). Notably, for all of the analyses of the impact of new technologies in finance; and of the digital platform economy outside of finance; there has not been a systematic evaluation of the impact of the digital platform model on asset management. Here we fill this gap, by (1) building a modified Global Financial Network (GFN) framework for conceptualizing the organizational and geographic logic of the digital platform economy in finance, and (2) examining the deepening impact of the digital platform model on asset management.

As we will show, asset management is being profoundly disrupted by the rise of what we dub digital asset management platforms-or DAMPs - which encompass a vertically integrated set of services ranging from index fund and ETF provision, to robo-advising, to thirdparty analytics and trading support. Like other digital platforms, DAMPs do not so much leverage technology to enhance their competitiveness within markets, as to radically restructure the market itself. Moreover, as for other platforms, their rise has been associated with a paradox of centralization through democratization, wherein reductions in customer costs are counterintuitively coupled to oligopoly or monopoly. However, we also show that the peculiar characteristics of the financial sector-and above all, the extent to which it already resembles the digital platform economy in its informational intensity, and organizational and regulatory fluidity-have led to differences in the logic and implications of the rise of DAMPs, in comparison to other industries. In particular, DAMPs (1) have tended to asymmetrically disrupt different dimensions of market efficiency, ${ }^{1}(2)$ are generally less suited to regulatory arbitrage than other tools already at the disposal of financial firms, and (3) have mostly reinforced rather than challenged the position of incumbent asset management firms and centers.

The remainder of the paper is divided into eight sections. In section two we review the digital platform economy, before examining in section three how its logic interacts with the unique characteristics of the financial sector. From a geographic standpoint, we propose an adapted version of Coe et al.'s (2014) Global Financial Network (GFN) framework for problematizing the deepening impact of information technology on finance. Next, in section four, we examine the business models of the most important DAMPs, before demonstrating, in section five, how these have produced a classic digital platform paradox of centralization through democratization. In sections six, seven, and eight we probe the geographic dimensions of the rise of DAMPs, before concluding with a discussion of the broader implications of this business model in asset management and finance.

\section{The digital platform economy}

There is a growing awareness that the information age economy is dominated by a specific organizational form, dubbed the "digital platform economy" (Kenney and Zysman, 2016; Evans and Gawer, 2016; Langley and Leyshon, 2017). The digital platform economy can be

\footnotetext{
${ }^{1}$ Specifically "information-arbitrage," "fundamental valuation" and "functional" efficiency (Tobin, 1984).
}

conceptualized as a collection of technology-enabled hub-and-spokes business models, wherein a platform-providing lead firm coordinates the activities of platform users. As noted by Evans and Gawer (2016), there are two basic types of digital platform. The first (e.g. operating systems) establish a core of tools and standards that serve as a foundation for third-party software or content. Meanwhile, the second establish a marketplace wherein various categories of user transact with one another, and/or the platform provider itself.

The line between these platform types is blurry. Broadly speaking, however, it is the second that has been associated with the "disruption" of traditionally non-ICT-centered industries, including advertising, taxi service, accommodation, and retail. This disruption generally follows a stereotyped pattern, wherein the cost of a goods or service is dramatically reduced through some mixture of both technology-enabled efficiency enhancement, and technology-enabled organizational arbitrage.

Firstly, the disruptive potential of platforms typically stems from their enhancement of market "efficiency," such that incumbent intermediaries or participants are rendered obsolete (Langley and Leyshon, 2017). ${ }^{2}$ Platforms typically boost multiple dimensions of efficiency in a complementary manner (Edelman and Geradin, 2015), with an emphasis on "allocative efficiency"-i.e. setting prices at a market-clearing rate with respect to supply and demand- "informational efficiency"-i.e. the extent to which prices reflect informed assessments and expectations of the past, present, and future-and finally what Tobin (1984) dubs market "functional efficiency"-i.e. the overhead costs of the pricing process compared to the socio-economic value it provides. At the center of the enhancement of all three, for most platforms, are "big-data"-fed analytics. In online advertising for example, this entails analyzing user data to determine exactly how much a user's clicks/views are worth to whom in any given context, thus ensuring optimal advertising spending allocation. Automation of the whole process drives costs to the lowest possible level. Also important to market efficiency enhancement, for many platforms, is intensified producer competition enabled by reduced market entry barriers. Ridesharing services, for example, optimize supply-demand matching not only by calculating exactly how much rides should cost in a particular time and place (e.g. "surge pricing"), but by enabling individuals to become drivers (Edelman and Geradin, 2015).

Platforms nearly always provide some genuine technology-enabled market "efficiency" enhancement. However, platform competitiveness also typically rests, at least partially, on technology-enabled organizational arbitrage; usually made possible by the control that platform providers gain over markets in the process of enhancing their efficiency (Edelman and Geradin, 2015; Langley and Leyshon, 2017). Most importantly, providers are typically able to externalize various costs to users. Often, this is done by harvesting users' "digital labor" (or "digital exhaust") (Fumagalli et al., 2018; Neef, 2014). In other cases (e.g. the "gig" economy), platform providers serve as brokers coordinating the delivery of paid services, meaning that customer income cannot simply be pocketed without compensating producers. Even here, however, providers typically externalize the largest possible component of cost$\mathrm{s}$ - usually by leveraging platform control to blur the boundary between market and hierarchical coordination (e.g. reclassifying employmentlike relations as subcontracting). This often entails a business model predicated on arbitraging labor and other regulations, with the spread of digital platforms thus a legally and politically contentious process (Davies et al., 2017; Edelman and Geradin, 2015).

Taken as a whole, digital platforms have pushed the information economy in counterintuitive directions-particularly when viewed against the rather utopian predictions of the early internet era. On the one hand, their rise has intensified the paradox noted by Lessig (2006),

\footnotetext{
${ }^{2}$ According to Langley and Leyshon (2017), "The underlying intermediary logic of the platform is that it solves coordination problems in market exchange by extending the distance-shrinking networking capacities of the internet."
} 
wherein the very features of cyberspace that make it resistant to state regulatory authority-namely its organizational and geographic slipperiness-have encouraged the emergence of countervailing "sovereigns of everywhere," with an increasingly pervasive and intrusive reach. Meanwhile, even more striking is what can be dubbed the digital platform paradox of centralization through democratization (Acquier et al., 2017; Langley and Leyshon, 2017). Platforms are democratizing insofar as they offer reduced costs and increased convenience for customers, and/or lower entry barriers for producers. However, they also create new privately-controlled market choke points, with a "winnertake-all" concentration of market share at the level of platform providers typically fostered by powerful interlocking increasing returns (Economist, 2018c). First are "network effects" wherein new users further enhance platform attractiveness to other users. Second are databased returns to scale, wherein "More information lets firms develop better services, which attracts more users, which in-turn generate more data" (Economist, 2018d). Third are conventional scale economies stemming from the predominantly fixed cost structure of platforms (itself often a product of how providers can pick and choose which costs to internalize versus externalize to users). Crucially, the paradox of centralization through democratization also operates geographically, with the "superstar effect" in knowledge-driven industries more often exacerbating regional inequalities than creating an ICT-enabled level competitive playing field (Davies et al., 2017; Quah, 1996).

\section{Finance as a digital platform industry: A global financial network perspective}

Our argument is that technological disruption in finance is increasingly converging on the digital platform model. However, finance has unusual characteristics that have caused this to occur in a different manner from other industries. Ironically, these differences stem from the extent to which two key features of the digital platform economy have always been central to finance; namely its informational intensity, and regulatory and organizational fluidity.

Firstly, harnessing the power of "big data" to maximize market efficiency is more evolutionary than revolutionary in finance. Indeed, gathering and processing market information has always been the industry's lifeblood (Wójcik, 2011). From the standpoint of digital platform development, what is most important is that the financial sector's massive existing apparatus of information gathering and processing has, as noted by Tobin (1984), long produced a sharply asymmetrical development of different aspects of market "efficiency"-particularly in the securities market. Firstly, from an informational standpoint, financial markets tend to be characterized by much higher "information arbitrage efficiency" than "fundamental valuation efficiency." "Information arbitrage efficiency" is high in the sense that the market is so overcrowded with investors seeking to identify and exploit opportunities for pricing arbitrage, that it becomes difficult for anyone to consistently outsmart the market consensus. However, this does not mean that the consensus itself is particularly good at anticipating and pricing future events-as evidenced by volatility levels far in excess of changes in underlying fundamentals (Schiller, 2003; Tobin, 1994). Indeed, the same liquidity that enables "information arbitrage efficiency" may undermine "fundamental valuation efficiency" by facilitating speculative manias and other pathologies.

Also very low, Tobin argues, is the "functional efficiency" of financial markets, as defined by the extent to which their operational costs (salaries, profits, etc.) are justified by the services they perform. From Tobin's standpoint, the key question is value to society. However, finance's "functional efficiency" is arguably also quite low for market participants. Indeed, as for fundamental valuation efficiency, low functional efficiency appears to be a counterintuitive corollary of high information arbitrage efficiency, as the same overcrowding of securities markets that allows for information to be rapidly incorporated into prices undermines the ability of participants to make money (see
Section 4). There is overwhelming evidence that nearly all fund managers underperform market average indices once operational costs are deducted (Malkiel, 2013).

Taken as a whole, these disconnects between different aspects of financial market "efficiency" imply that the conventional digital platform pattern of disrupting industries by simultaneously boosting all aspects of market efficiency, in a complementary manner, is unlikely to find much purchase in finance. Rather, platforms are likely to operate asymmetrically on different aspects of efficiency.

Just as striking as the parallels between the informational intensity of the digital platform economy, and finance as traditionally structured, are their parallel organizational and geographic fluidity. The activities of financial firms, like digital platform providers, are enormously consequential for the "real" economy. However, the products directly provided by both are mostly constituted, in a literal sense, of abstract textual and numerical "code." Of primary importance in finance are private contracts (Haberly and Wójcik, 2017a; Knuth and Potts, 2015; Pistor, 2013). Like software, these contracts can, at least in commonlaw based systems, be crafted in almost unlimited innovative ways so long as they remain within the bounds of public law and regulation-which are themselves mutable via choice of jurisdictional arena and political lobbying. The result is a deep structural commonality between the dialectics of legal-regulatory innovation/avoidance/ mobility, and state regulatory response, in finance and cyberspace (Ferri and Minsky, 1992; Lessig, 2006); however a commonality in which Silicon Valley, for all of its recent controversies, is an amateur when compared to Wall Street or The City. The question this raises is whether the emergence of a new financial technological architecture will have any impact on the basic logic of this dialectic of regulatory avoidance and reaction, or simply define a new chapter in an old story.

Crucially, none of these questions can be addressed in a geographic vacuum. As financial geographers have long observed, the informational efficiency of financial markets must be generated by the human and material apparatus of financial centers (Cook et al., 2007; Wójcik, 2011; Zook and Grote, 2017). The key question is how the "old" human-relational informational geography of finance will interact with its increasingly important "new" virtual informational geography—and just as importantly, the geography of behind-the-scenes technicians who craft its algorithms. Similarly, geographers (e.g. Roberts, 1994; Coe et al., 2014; Haberly and Wójcik, 2017a; Knuth and Potts, 2015) have long emphasized that the abstract legal-regulatory dimension of finance must be structured through real places-even if only law offices housing the documentation of "brass plate" companies. In this respect, the key question is how this "paper" geography of finance will interact with the growing importance of its "virtual" geography.

Addressing these questions requires an analytical framework that conceptualizes the evolution of financial geographies in terms of the intersection of multiple, qualitatively different geographic logics, rather than simply an overarching logic of financial center agglomeration. The outline of such an approach is provided by the Global Financial Network (GFN) framework introduced by Coe et al. (2014), which conceptualizes the geography of finance as a multidimensional logic of financial center specialization across different functional spheres. As has been widely acknowledged (see Töpfer, 2018; Wójcik, 2018), this framework is something of an initial sketch, which requires elaboration to be fully operationalized. Consequently, in Fig. 1, we outline an expanded GFN approach to conceptualizing the geographic evolution of FinTech. In contrast to Coe et al.'s "2D"-framework, this problematizes financial geographies in terms of the four-pronged interactions between what we dub the "relational," "virtual," "technical," and "paper" geographies of finance. Each sphere has its own logic of centripetal and centrifugal processes-both internally and in relation to other spheres-which are seen as combining to condition the role and formation of particular financial centers.

Implicit in this framework is the potential for a technology-enabled centrifugal unbundling of the geography of finance. In the most extreme 


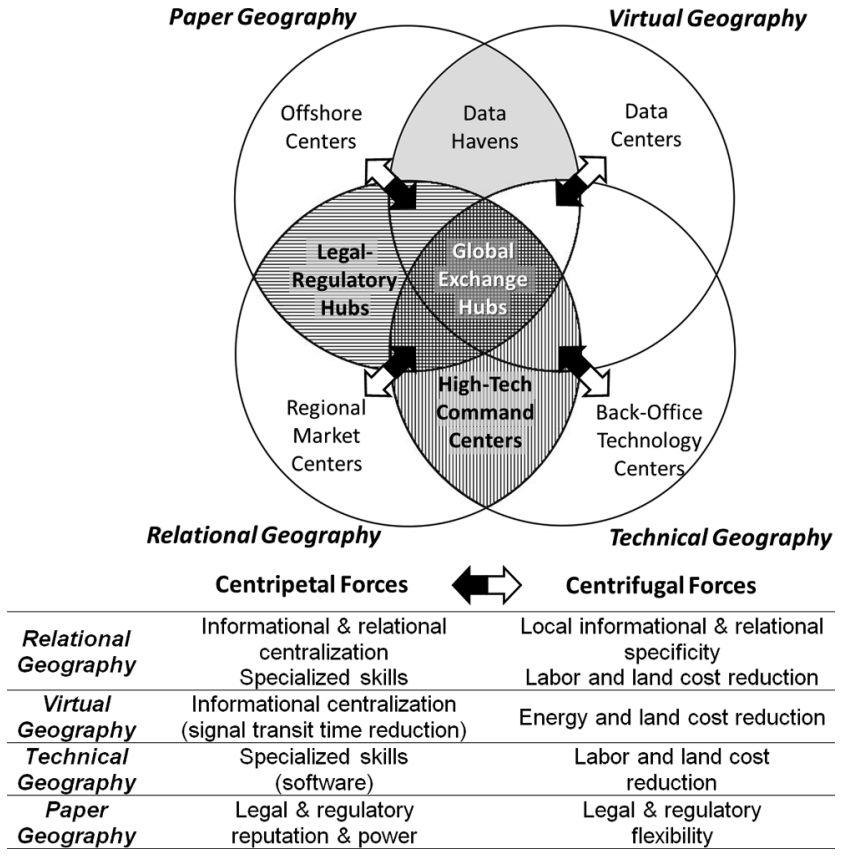

Fig. 1. Modified Global Financial Network (GFN) Framework.

scenario, incumbent global financial market clearinghouses and command centers might be rendered obsolete by the rise of four-pronged decentralized networks. In these networks, the core market informational processing functions of finance would increasingly be performed by computerized data centers located wherever land and energy are cheapest (see Jaeger et al., 2009). Meanwhile, human labor would increasingly be bifurcated between back-office technical and front-office client relational roles. In theory, neither need be located near each other, nor near data centers. Technical jobs might gravitate towards "back-office technology centers," with Silicon Valley (and its international low-wage offshoots) perhaps "eating" the bulk of financial industry employment and value. Meanwhile, the remaining relational roles in finance might be dispersed to "regional market centers" embedded within locally specific bodies of knowledge and relationships (see Dixon and Monk, 2014).

Finally, the "paper" organization of financial vehicles and contracts need not correspond to any of these three layers, but rather might reside in an offshore network offering maximum legal and regulatory flexibility. As financial activity becomes increasingly "virtual," onshore jurisdictional connecting factors might be severed by financial "data havens"-i.e. offshore jurisdictions which attract electronic transactions and record-keeping (Jaeger et al., 2009). As shown in Fig. 2, the British Virgin Islands and Seychelles already have far more servers per capita than any other countries/jurisdictions. Several offshore jurisdictions are jostling to become cryptocurrency hubs (Kahn, 2015).

Some elements of this scenario of technologically-driven financial geographic unbundling are clearly unfolding. However, there is reason to believe that it is unlikely to progress to extremity, due to the operation of countervailing centripetal forces both within and between each of the four functional spheres in Fig. 1. Firstly, the "virtual" geography of financial market information processing is less unmoored from the traditional "relational" geography of financial centers than might be expected (Wójcik, 2011; Zook and Grote, 2017). For trading, the information technology-enabled acceleration of transaction pace has more than canceled-out any communications technology-enabled compression of distance, with trader servers clustering near securities exchanges to gain a fleeting advantage in signal travel time. From both a human and machine standpoint, these locations-which we dub "global exchange hubs" in Fig. 1-remain the leading global financial command centers. For the most part, these are the same places that have long been dominant in this respect (e.g. New York, London); indeed, as detailed by Wójcik (2011), technology has overwhelmingly promoted a further concentration of securities market activity-both human and electronic - in already dominant centers. To the extent that spatial diffusion occurs, it appears to be largely within these exchange hubs, with activities sprawling outwards from traditional financial districts into ever-larger global financial city-regions (e.g. Mahwah, NJ and Stamford, CT are respectively the centers of exchange/trader servers and hedge fund management for New York).

Meanwhile, the space for an unbundling of the "paper" offshore legal-regulatory geography of finance from the "real" geography of financial centers is narrowing. Decades of efforts to combat offshore tax and regulatory arbitrage by expanding the extraterritorial jurisdiction of onshore states have increasingly forced offshore centers to operate with one (or both) feet inside of onshore regulatory frameworks (Roberts, 1994; Haberly and Wójcik, 2017a). In the most extreme case, the Chinese government has directly undertaken the construction and operation of offshore state-owned enterprise listing and RMB trading facilities (Hall, 2017; Wójcik and Camilleri, 2015). More broadly, for prudential regulation, the Basel framework has tackled Euromarket arbitrage by assigning global supervision of multinational banks to the home states where they are headquartered (D'Hulster, 2012). Meanwhile, securities regulatory jurisdiction (particularly for the US) is increasingly defined substantively based on to and by whom and where securities are promoted, traded, and sold, with paper vehicle domicile of decreasing relevance (Chang, 2003; Haberly and Wójcik, 2017a). Finally, political pressure on tax havens has prompted firms to seek

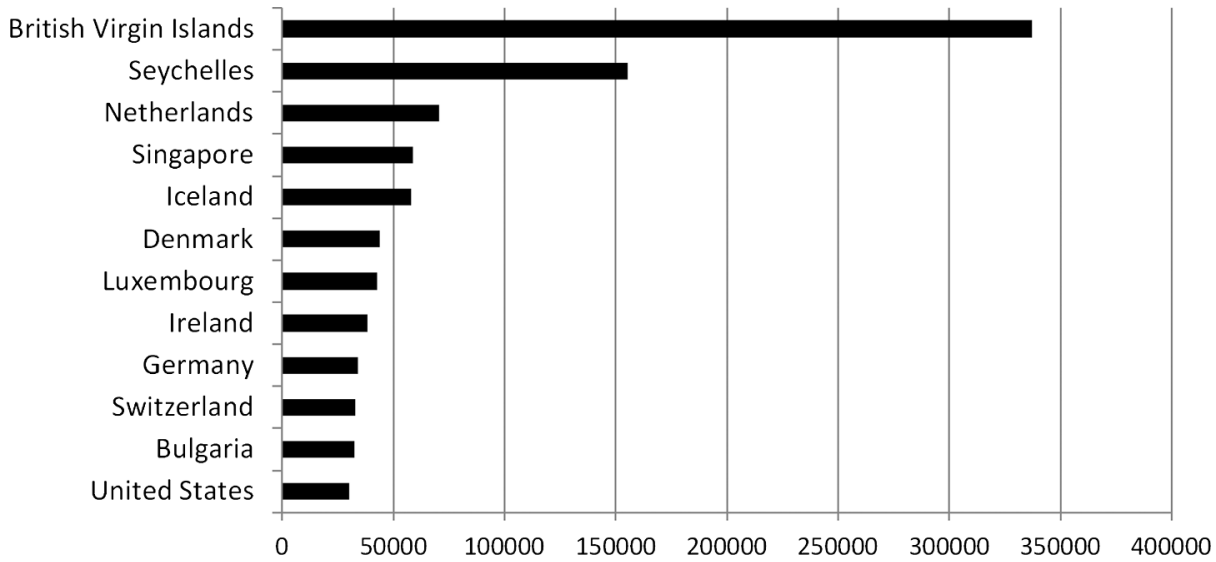

Fig. 2. Servers Per Million Inhabitants, 2017.

Source: World Bank. 


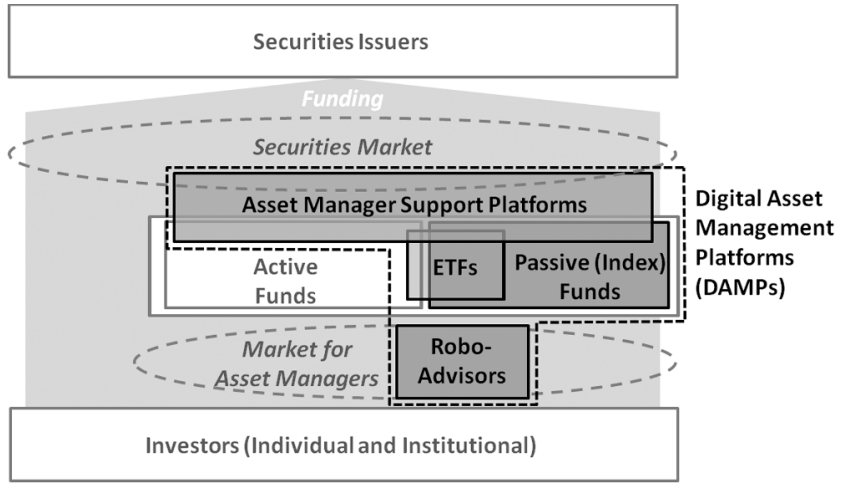

Fig. 3. Digital Asset Management Platforms (DAMPs).

plausible deniability by using larger (e.g. OECD) havens (Economist, 2013a). As shown in Fig. 1, the paper geography of finance thus remains anchored by what can be dubbed "legal-regulatory hubs" located within the dominant traditional financial centers-and above all the leading "global exchange hubs." This is not just a public regulatory issue, but also entangled with the role of these centers as hubs for private contractual law, wherein jurisdictional reputation and accumulated legal precedent are of paramount importance. Indeed, the most influential legal frameworks (e.g. New York) provide the basis for global financial law export industries (Knuth and Potts, 2015).

Finally, the "technical" and "relational" geographies of finance are entangled with both one another and the "paper" geography of finance. Regardless of whether humans are removed from directly performing activities (e.g. stock-picking), the technical side of finance must be embedded in higher-order sector-specific skills and strategy, responsive to a rapidly changing competitive landscape. It is unclear whether "back-office technology-centers" can, regardless of software expertise, compete with established financial centers in these respects. Particularly notable is that financial innovation must, regardless of technological content, involve "paper" contractual innovation requiring a deep expertise in relevant areas of law and regulation (see Haberly and Wójcik, 2017a). This entails not only familiarity with current regulation, but also expertise and investment in the type of sustained political engagement necessary to shape regulation. Notably, most of the largest Silicon Valley firms, including Google and Amazon, have so far been deterred from entering financial services by the unfamiliar and high-risk regulatory complexities this would entail (Willmer and Kumar, 2017). While Facebook is now braving these waters with its Libra cryptocurrency project, it appears to be doing a remarkably poor job of navigating their regulatory and political dimensions (see conclusion)—particularly if one compares it to, for example, the political adeptness of Wall Street investment banks at promoting financial innovation prior to the global financial crisis (see Wójcik, 2012). Meanwhile, the burgeoning scale of New York's FinTech industry underscores the capacity for the largest financial legal-regulatory and exchange hubs to become centers of finance-specific software expertise (Gach and Gotsch, 2016).

In the remainder of the paper, we put the pieces from the previous two sections together to examine the deepening technological disruption of asset management. As we show, this disruption closely follows the pattern seen in other sectors insofar as it exhibits both (1) a digital platform model of undercutting incumbent cost structures by boosting various aspects of market efficiency, and (2) the associated digital platform economy paradox of centralization through democratization. However, the factors outlined in this section have also resulted in notable divergences of the pattern of technological disruption from that seen in non-financial sectors.

\section{The rise of Digital Asset Management Platforms (DAMPs)}

Asset management is in many respects a natural fit for the digital platform economy insofar as managers do not intermediate funds through their own balance sheets, but rather act as matchmakers between securities issuers and investors. Until recently, however, this commonality with the platform economy model has been overshadowed by a paradigm of asset manager competition that is essentially the platform model's antithesis. Rather than acting as low-cost, transparent conduits between investors and the securities market, this has entailed managers charging high fees to cover high costs-particularly highly-paid labor-incurred in an attempt to beat the returns of their peers (Bernstein, 2005; Malkiel, 2013).

The growing computational intensity of asset management has not necessarily challenged this traditional business model. "Quant" hedge funds, for example, essentially just substitute high-cost superstar algorithms for high-cost superstar stock-pickers. In terms of the sheer amount of money involved, however, this computerized replication of the traditional high-cost fund management model has increasingly been overshadowed by the rise of what we dub "digital asset management platforms" (DAMPs). Rather than using technology to gain a competitive edge within the securities market, DAMPs fundamentally restructure the market itself, generating enormous cost savings for investors, and radically disrupting incumbent business models.

As shown in Fig. 3, there are four key types of DAMP. Oldest are index (passive) funds, which are very simple algorithmic funds that minimize investor fees by simply "buying the market." These funds piggyback on the high preexisting information arbitrage efficiency of securities markets to dramatically enhance market functional efficiency. Exchange Traded Funds (ETFs) are a subset of index funds which further enhance functional efficiency by restructuring the fund management process as a two-sided market platform. Lying between fund managers and the securities market-and blurring the boundary between managers and the market-are "asset manager support platforms." These provide services to both active and passive managers including portfolio risk management, trading optimization and execution, and regulatory compliance support. In contrast to the simplicity of index funds, these employ sophisticated data-driven analytics to enhance both the fundamental valuation efficiency and functional efficiency of the securities market. Finally, the newest DAMPs are "roboadvisors," which in practice largely act as ETF distributors. Robo-advisors bear the closest resemblance to digital platforms outside of finance in that they simultaneously boost all aspects of market efficiency, in a complementary manner, in the retail market for fund managers-as opposed to the securities market itself.

Arguably the oldest exemplar of the digital platform model, either in or outside of finance, is the index fund. Index funds were conceived as a thought experiment accompanying the development of the efficient market hypothesis (EMH). By using the first generation of reasonably powerful computers to perform empirical statistical analysis (Bernstein, 2005), early EMH researchers identified a conundrum in US securities markets; the same overcrowding of markets with participants that allowed for newly released information to be rapidly incorporated into prices, depleted the actionable arbitrage opportunities on which participants depended to make money (see Fama, 1995; Malkiel, 2013). The problem was that searching for and exploiting the residual arbitrage opportunities was expensive. Net of costs (research, trading, etc.), Ellis (1975) found that $85 \%$ of US fund managers had underperformed the $S$ \&P 500 index-i.e. what could be more or less expected from simply buying stocks at random-over the previous decade. In Tobin's (1984) terminology, this implied that market "information arbitrage efficiency" was vastly higher than "functional efficiency."

Early EMH claims regarding securities market efficiency are controversial (Tobin, 1984); however, what has been robust is the specific finding that information arbitrage efficiency is, at least in the US, high enough to translate into very low asset manager functional efficiency 
(i.e. returns net of costs; Malkiel, 2013). It is this practical observation that has driven the rise of index funds, which are very simple algorithmic funds that allow investors to passively buy and hold a crosssection of the entire market-thus eliminating the conventional fund management apparatus of analysts, traders, etc. Rather than chasing gross returns at any cost, index funds compete on price, maximizing net returns by driving down operational overheads to the lowest possible level, while earning a gross return exactly equal to the market average (Bernstein, 2005; Malkiel, 2013).

By serving as cheap and transparent vehicles for investors to "buy the market," index funds fundamentally transform asset management-above all by radically undercutting industry fees and employment. Unsurprisingly, they were fiercely resisted by the industry when first proposed by academics, and ultimately would not be pioneered in the money centers of the northeast, but rather a triangular network linking the San Francisco Bay area to MIT and the University of Chicago (Bernstein, 2005). Playing a key role in establishing this network was an analyst at Smith Barney, John McQuown, who had personal connections to finance researchers at the University of Chicago, and in 1963 began working with an MIT computer scientist to develop algorithmic investing techniques. Their IBM mainframe rentals attracted the attention of "IBM people, who were always on the lookout for anything that might demonstrate to prospective customers the versatility and power of the computer" (Bernstein, 2005, p. 210). Via an IBM executive forum in San Jose, McQuown was invited to implement algorithmic investing at San Francisco-based Wells Fargo. Despite opposition from colleagues alarmed by the "...guys in white smocks with computers whirring” (Bernstein, 2005, p. 213), McQuown's project would, with consultative input from many leading academic finance figures (including Eugene Fama), radically transform the bank's approach to investment management. Ironically, indexing was adopted "by default," as even this simplest algorithmic strategy was "a nightmare" to implement on 1970s-era computers. However, having launched the first indexed products in 1971, the management of Wells Fargo had by the end of the 1970s become so impressed with these that they decided to eliminate conventional active fund management (Bernstein, 2005).

The San Francisco-based operation established by Wells Fargo remains the market leader in indexed products-notwithstanding changes in ownership from its reorganization as a joint venture with Nikko Securities in 1990, to its sale to Barclays in 1995, and finally its purchase by BlackRock in 2009. During this time, two additional developments have impacted index investing. The first was the launch of the first index mutual fund-open to small retail investors-by Vanguard in 1975. The second was the development of the Exchange Traded Fund (ETF) in the late-1980s and early-1990s.

Whereas index funds transform the relationship between investors and securities markets, ETFs transform securities markets themselves by allowing market indices to be repackaged and traded as securities on these markets. ETFs are not managed like conventional funds, but are rather structured as two-sided market platforms. On one side, investors buy and sell ETF shares on the secondary market; on the other, arbitrageurs (e.g. investment banks) exchange specified baskets of securities with the ETF for "creation units"-i.e. primary market ETF share issues and repurchases-such that alignment is maintained between (1) the market value of the ETF's portfolio and the market value of its shares, and (2) ETF portfolio composition and the index it tracks. This platform architecture allows ETFs to achieve exceptionally low operational costs. ETF are also more liquid than conventional mutual funds, with intra-day trading possible (Hill et al., 2015).

Although index funds have grown rapidly since the 1970s, it is only since the global financial crisis that their inflows have become so large as to reduce the total AUM of active funds (Fig. 4). Since 2007, the indexed share of US equity fund AUM has nearly tripled to $43 \%$, with ETFs accounting for approximately $40 \%$ of this (Sushko and Turner, 2018). Theoretically, there should be a ceiling on passive fund growth, as it will eventually impair the information arbitrage efficiency of markets, creating new arbitrage opportunities for active investors. However, this has not happened so far. Over $2006-2016,82 \%$ of active US equity funds underperformed the S\&P index benchmark (S\&P, 2017), essentially the same as the $85 \%$ found by Ellis (1975). Furthermore, similar shares of international funds have underperformed their respective benchmarks (see S\&P, 2017), driving a rapid growth of passive investing in major securities markets outside of the US (see Fig. 4 and Sushko and Turner, 2018). As shown in Fig. 5, the cost advantage of passive over active funds is actually widening in ratio terms. Indeed, the trend is towards a zero-fee model of index funds and ETFs as cross-subsidized multi-sided markets-with the first zero-fee funds recently launched by Fidelity-wherein fund investors cease to be paying customers, and rather become a resource enabling the accumulation of liquid securities that can be profitably lent to investment banks and short-sellers (Kaisser, 2018).

The early development of index funds can be attributed to their ability to use extremely simple algorithms to boost the securities market's relatively low level functional efficiency, by piggybacking on the market's much higher level of information-arbitrage efficiency-in other words, their harnessing of the ready-made "computer" of the market. However, as computing power has increased, new DAMPs have emerged that bear a closer resemblance to the stereotyped digital platform model of employing sophisticated analytics to boost multidimensional market efficiency. Most influential are what can be dubbed "asset manager support platforms" (Fig. 3), and above all BlackRock's Aladdin. This was developed in the late-1980s as an in-house risk management tool for bond portfolios, and has subsequently expanded into a comprehensive "operating system"-or as CEO Larry Fink describes it, "the Android of finance" (Schatzker, 2017)—sold to asset managers as a cloud-based subscription. According to BlackRock (2018), "The Aladdin platform combines sophisticated risk analytics with comprehensive portfolio management, trading and operations tools on a single platform to power informed decision-making, effective risk management, efficient trading and operational scale." Aladdin's scale is staggering; from 2013 to 2017 the value of the assets it guided increased from $\$ 11$ trillion to $\$ 20$ trillion (Mooney, 2017). This is roughly equal to the capitalization of the New York Stock Exchange or the GDP of the United States. Moreover, Aladdin's importance to asset managers appears to be as deep as it is broad; according to the CEO of New York Life Investors: "Aladdin is like oxygen. Without it we wouldn't be able to function" (Gara, 2017).

Aladdin's heart can be described as a data-mining-powered enhancement of securities market "fundamental valuation efficiency." Reflecting its origins, what remain most important are portfolio risk management tools (Betz, 2016); as an example of their scope and power, one BlackRock fund manager recounts how Aladdin told him to purchase $\$ 400$ million in US treasuries to offset geopolitical risk from a North Korean missile test (Gara, 2017). In addition, Aladdin offers tools which broadly boost asset management "functional efficiency" in areas from trading optimization and execution (bypassing investment banks) to regulatory filing preparation. As Aladdin's scale, scope and sophistication have grown, it has increasingly blurred a number of boundaries; notably between human and algorithmic management (see Section 8), between BlackRock and other asset managers, between the internal operations of asset managers and the markets in which they operate, and ultimately, by extension, between BlackRock and the securities market as a whole. With respect to the last, Aladdin's risk management algorithms have become so influential as to raise concerns that they might actually create systemic risks, by inducing correlated market participant behavior (Economist, 2013b).

The newest area of DAMP development is robo-advising. Rather than the securities market, this targets the retail market for fund management products. At the most basic level, robo-advisors serve as online price comparison tools which steer clients into the lowest cost investment products; in practice usually ETFs (Kaya, 2017). However, robo-advisors also typically develop tailor-made product portfolios 

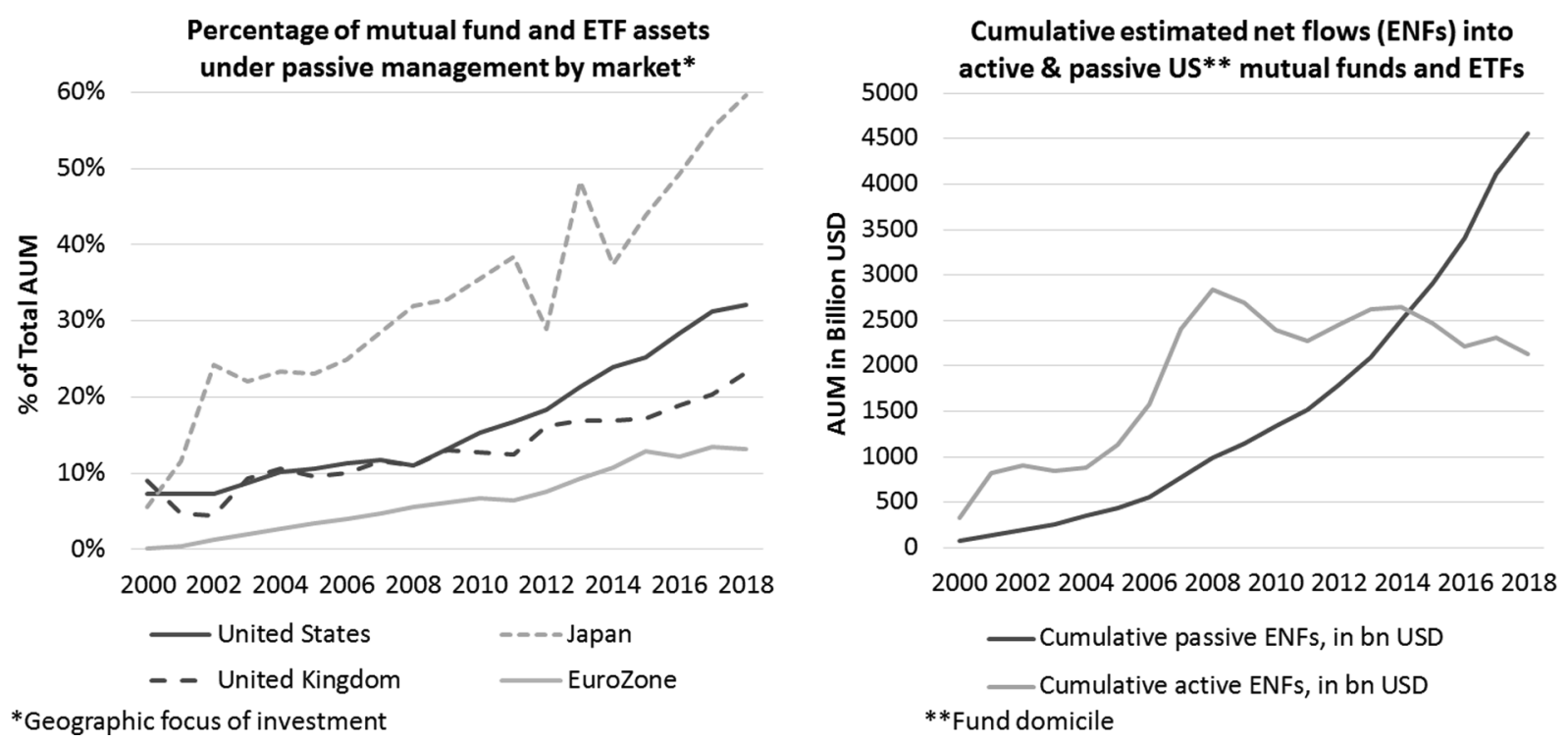

Fig. 4. Passive percentage of mutual fund and ETF AUM by market, and net flows into active and passive US mutual funds and ETFs, $2000-2018$. Source: Lipper.

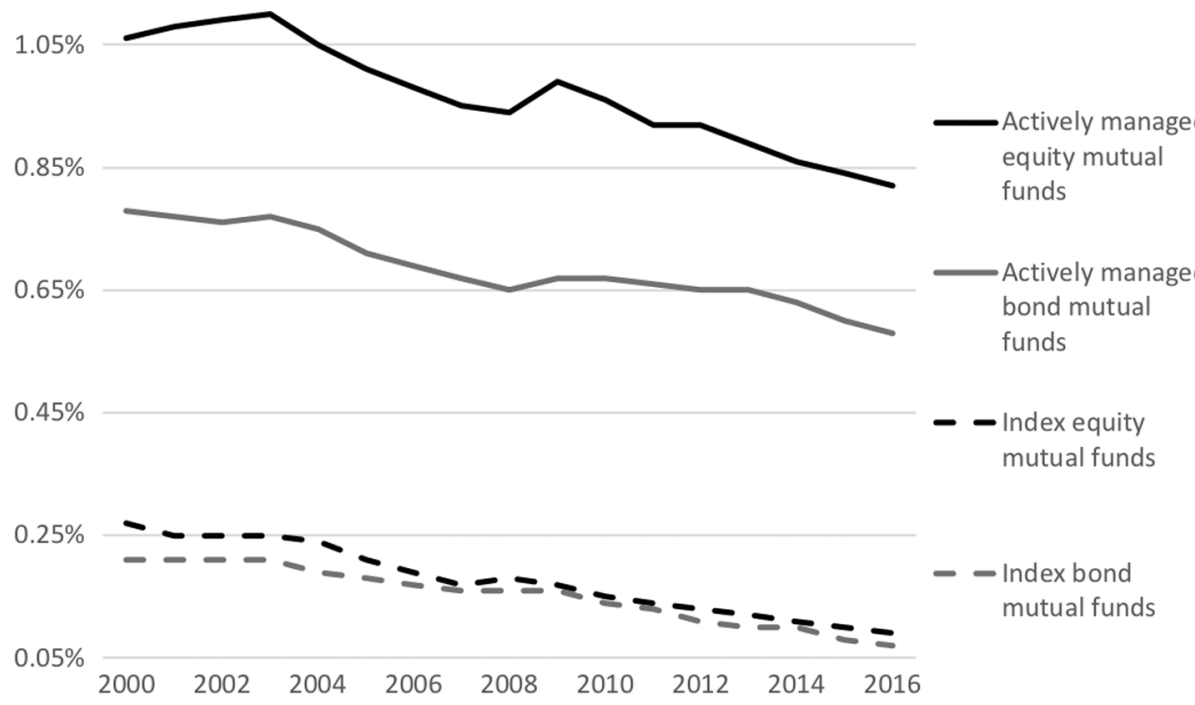

Fig. 5. (US) Active and passive mutual fund fees as a percent of AUM, 2000-2016.

Source: Urban, 2018.

based on client situation and preferences. The sector is still relatively small, with ca. $\$ 140$ billion AUM at YE-2017; however, it has been growing at 50-100\% per year (Mason, 2017). As we detail in Section 5, robo-advisors are increasingly becoming virtual "front offices" for sprawling vertically integrated DAMP ecosystems.

\section{A democratization of the capital market?}

A recurrent theme in FinTech discussions is the prediction of industry decentralization, with incumbent giants seen as threatened by innovative and nimble start-ups. Arner et al. (2016) go so far as to argue that the "new era of FinTech [is]...defined not by the financial products or services delivered but by who delivers them." In practice, however, the rise of DAMPs has produced a classic digital platform paradox of centralization through democratization. On the one hand, ETFs and robo-advisors offer users dramatically reduced costs, which arguably level the playing field in favor of smaller investors. Similarly, Aladdin's tool package provides smaller institutional (and increasing retail) investors with capabilities that were formerly available only to their larger peers. However, DAMPs also exhibit pronounced increasing returns that are producing a winner-take-all concentration of platform provider market share. Indeed, a remarkably large proportion of the asset management industry has come under the control of just three firms-BlackRock, Vanguard and State Street (see Haberly and Wójcik, 2017b; Fichtner et al., 2017). These increasingly act as not only horizontal monopolies/oligopolies within individual DAMP segments, but vertical monopolies which internalize control of all segments.

Figs. 6 and 7 show the pronounced concentration of index fund and ETF management, and how this has driven overall asset management industry concentration. As shown in Fig. 6, active management remains fragmented, with the 10 largest managers worldwide only having a $27 \%$ market share in 2016 . However, passive managers, with zero research costs, are able to realize almost unlimited scale economies once fixed costs are underwritten. The result is snowballing growth wherein increasing scale allows the largest providers to further reduce costs/ fees, which in-turn attracts additional clients (Haberly and Wójcik, 2017b; Malkiel, 2013; Sushko and Turner, 2018). The "big-three"-BlackRock, Vanguard, and State Street-control more than half of the 

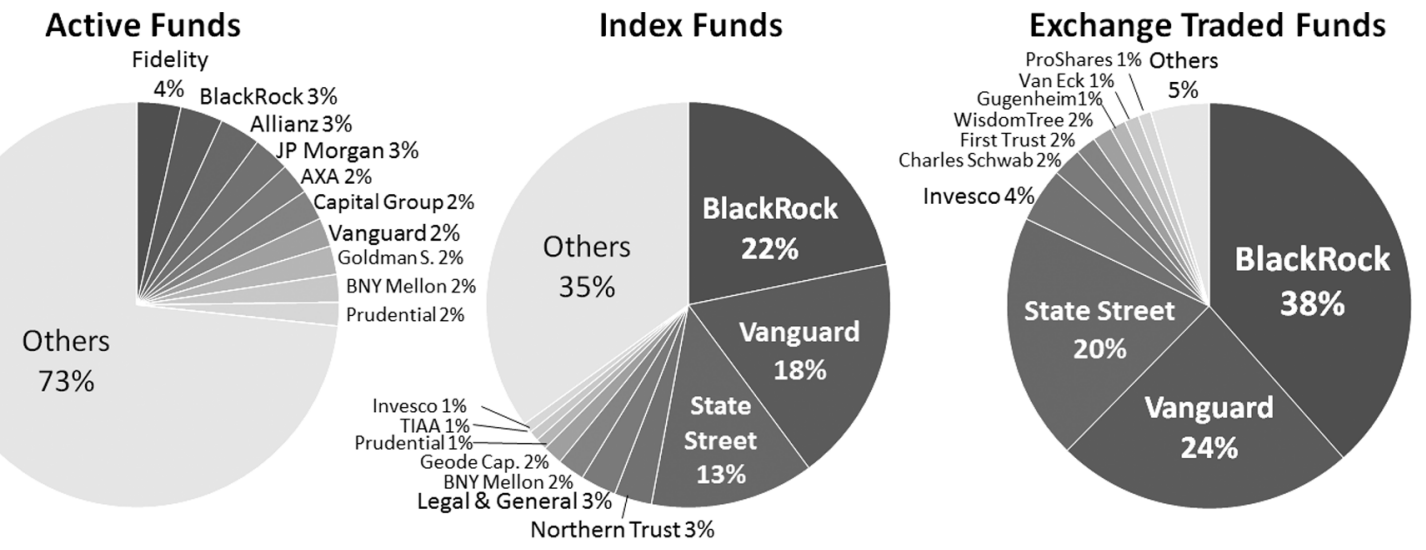

Source: Authors' calculations based on P\&I/Willis and Towers Watson, P\&I and PWC

Fig. 6. Worldwide market shares of top-10 managers of active, index (passive) and exchange traded funds (ETFs) in 2016.

\section{a. US asset manager market share change by size category}
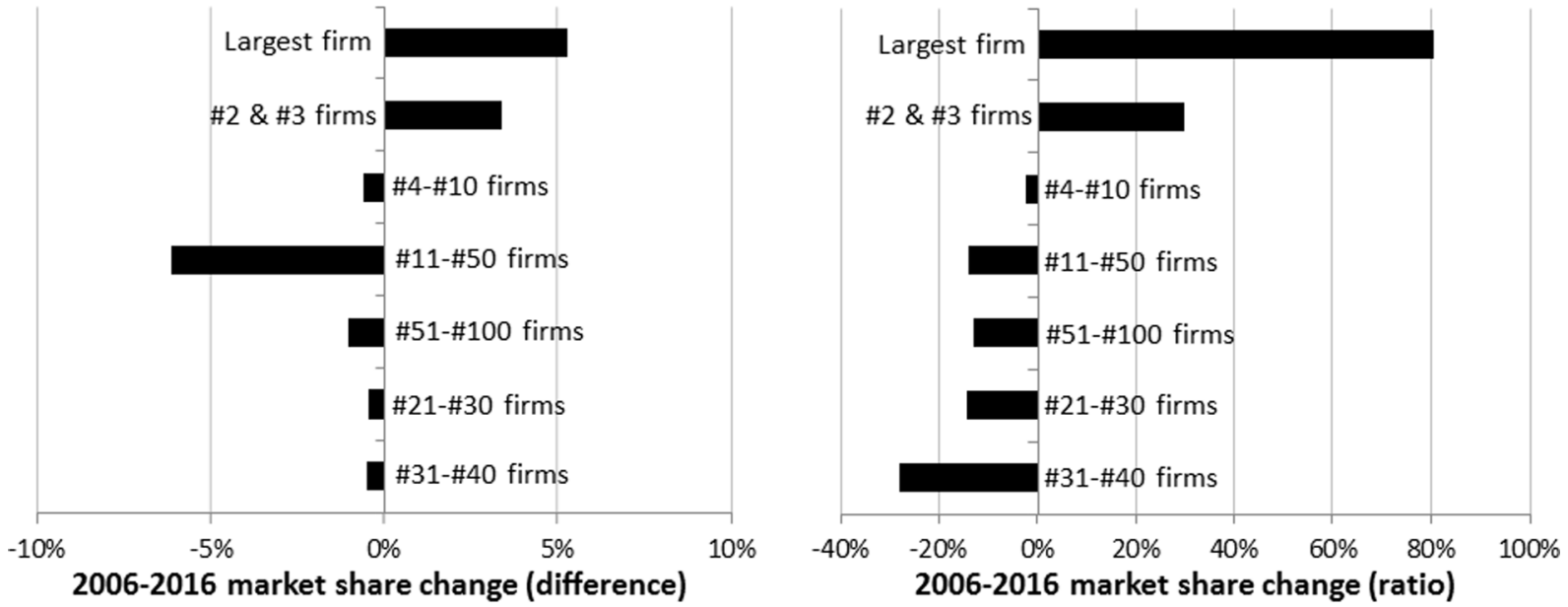

Each category compares the correspondingly ranked firms from 2006 and 2016.

\section{b. Worldwide asset manager market share change by size category}
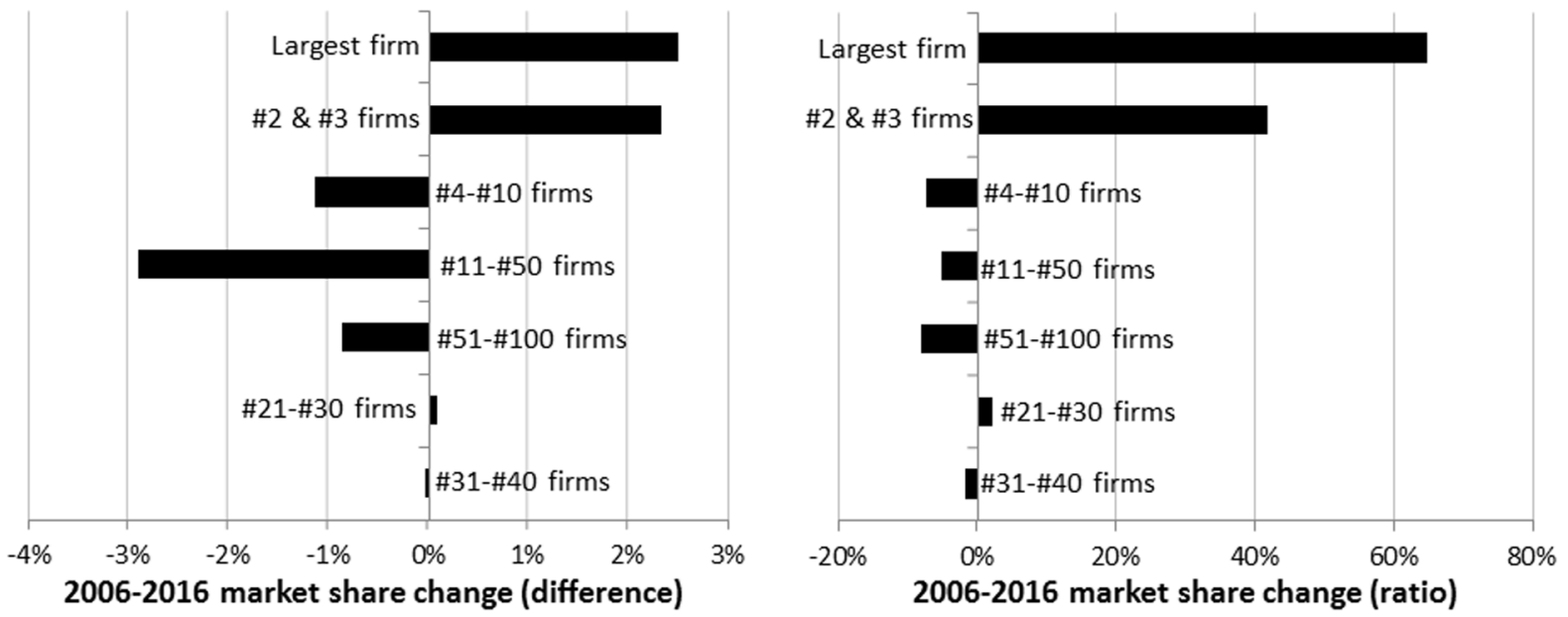

Each category compares the correspondingly ranked firms from 2006 and 2016.

Fig. 7. US (top) and worldwide (bottom) asset manager market share change by size category, 2006-2016. 


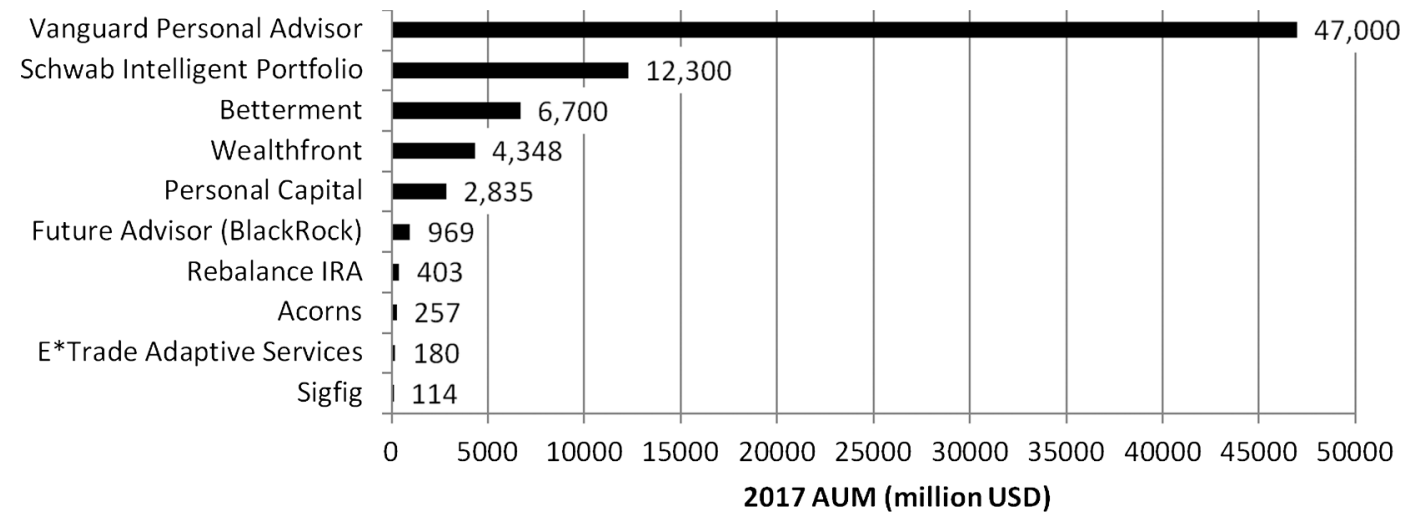

Fig. 8. Top-10 US Robo-Advisors 2017.

Source: Crigger (2017).

\section{a. US city-level asset manager headquarters concentration}
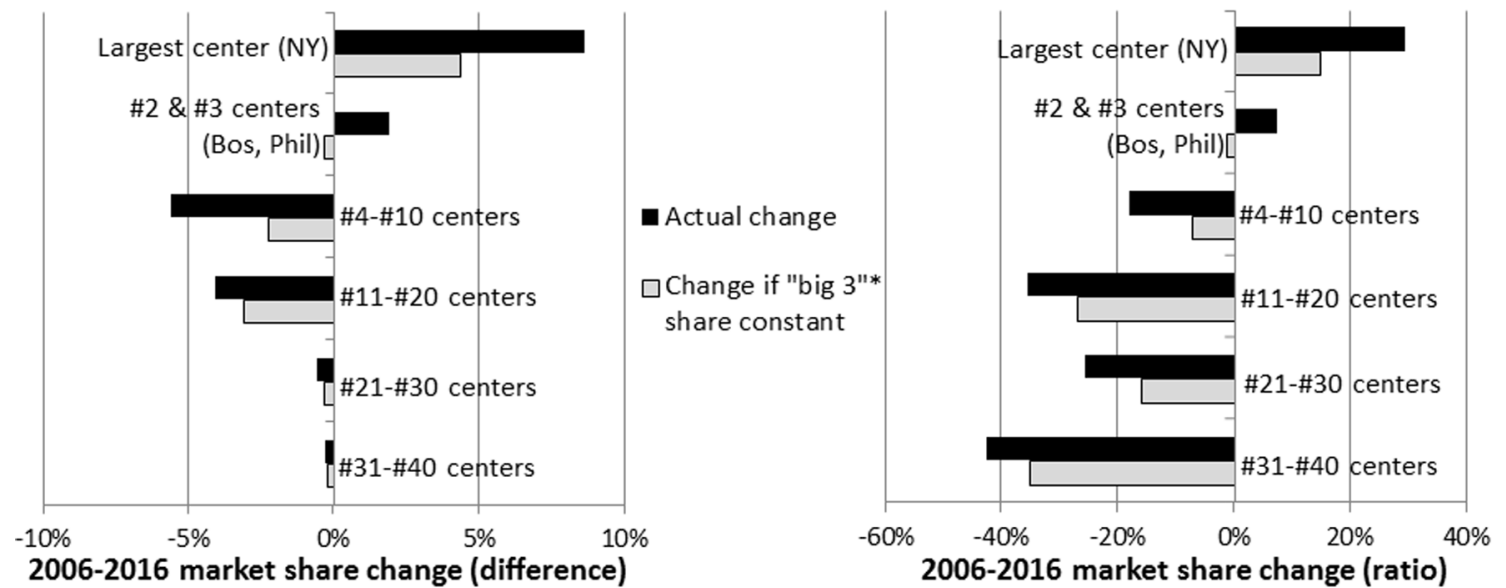

Each category compares the correspondingly ranked cities from 2006 and 2016. New York, Boston, and Philadelphia held the top-3 spots (respectively) in both 2006 and 2016.

*"Big three" refers to BlackRock, Vanguard, and State Street (headquartered in New York, Philadelphia, and Boston respectively)

\section{b. Worldwide city-level asset manager headquarters concentration}

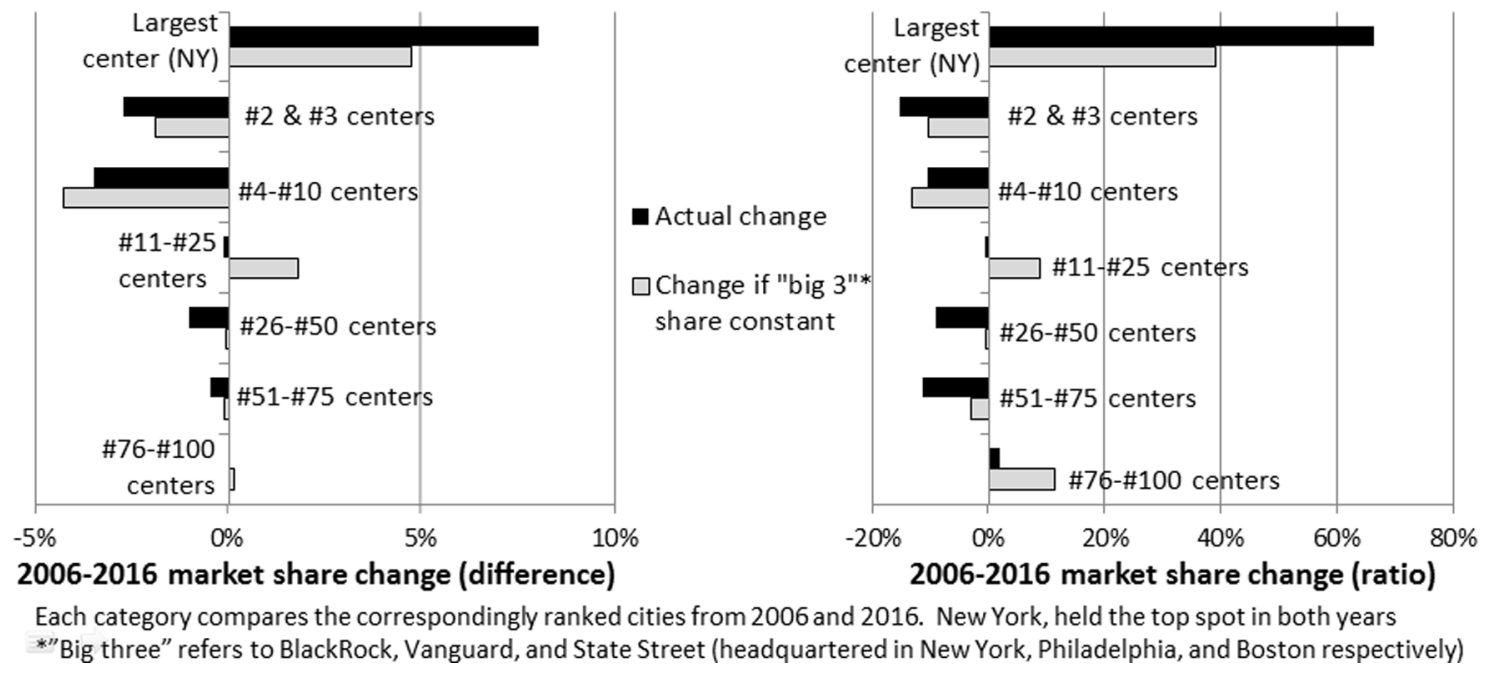

Fig. 9. US (top) and Worldwide (bottom) city-level asset manager headquarters concentration (with and without "big-three" passive manager growth). 
index fund market, while the top-10 firms control two thirds. Concentration is even more pronounced in ETFs due to network effects wherein ETF popularity increases liquidity, which in-turn increases popularity. The big-three have an $82 \%$ market share. BlackRock-dubbed the "Amazon of Wall Street" (Gara, 2017)—has a slightly higher ETF market share, via its iShares products, than Amazon has in online retail (38\% vs 37\%; Economist, 2018d).

As shown in Fig. 7 the rapid growth of index funds and ETFs from 2006 to 2016 produced a marked concentration of the asset management sector as a whole, at both the US and global level. Virtually all market share gains went to the big-3 passive managers-BlackRock, Vanguard, and State Street-while smaller firms lost market share. Remarkably, Vanguard alone accounted for more than half of the total inflows of the entire global fund management industry in 2016 (Economist, 2017). Concentration is even more pronounced once ancillary platforms are accounted for; the $\$ 20$ trillion in assets guided by Aladdin is three times larger than BlackRock's directly-managed funds.

Even robo-advising - whose development was spearheaded by startups-has developed a highly concentrated structure, in which roboadvisors act as virtual "front offices" for vertically integrated DAMP ecosystems (Mason, 2017). As one analyst puts it, "advice is ultimately a vehicle to unify control over client wealth" (McLaughlin, 2016). The second largest index fund and ETF manager, Vanguard, has a $50 \%$ greater market share than the next nine largest robo-advisors combined (Fig. 8), with its robo-advisor's recommendations appearing to consist almost exclusively of its own index funds and ETFs (Reklaitis, 2015). Its main long-term competitor appears to be BlackRock, which entered robo-advising through the 2015 purchase of FutureAdvisor as part of a push to make Aladdin for Wealth Management available for "every small account" (Schatzker, 2017), including "millions of retail investors" (Segal, 2016). In 2017, BlackRock expanded into the European robo-advisor market by purchasing Scalable Capital, "which uses exchange-traded funds from BlackRock and others to build low-cost portfolios for clients" (Jessop and Hunnicutt, 2017). In 2018, it extended its virtual front-office by investing in "micro-investing" mobile app Acorns, which "allows customers to automatically invest spare change from everyday purchases...in exchange-traded funds from BlackRock and Vanguard" (Rosenbaum, 2018).

\section{The geography of DAMPs I: Command-and-control}

Just as technological disruption has been predicted to decentralize firm-level financial industry structure, many have argued that the industry's geographic structure is likely to become more dispersed-or at least shift away from traditionally dominant centers. Tett (2018), for example, argues that managers are cutting costs by moving from New
York to lower-cost locations, with this move facilitated by the fact that "the internet makes it possible to trade securities and do research anywhere in the world." Indeed, Alliance Bernstein's 2018 headquarters move from New York to Nashville has led to suggestions that even the command-and-control functions of dominant financial centers are threatened by technology-driven cost-cutting (Clark and Buhayer, 2018). Furthermore, even if decentralization fails to materialize, this need not imply the continued leadership of incumbent centers; rather, as JP Morgan's CEO recently warned, finance might become the latest industry to be eaten by Silicon Valley (Dimon, 2014).

In fact, as shown in Figs. 9 and 10, neither of these scenarios is playing out, at least for command-and-control. Rather, 2006-2016 witnessed a clear tendency towards winner-take-all market share consolidation among US asset management centers (Fig. 9a). Combined with a transatlantic shift of industry dominance from Europe to the US (see Section 7), this produced a global winner-take-all city-level concentration trend (Fig. 9b), with the single largest center, New York, consuming $36 \%$ of worldwide market share gains (increasing its market share by $66 \%$ in ratio terms). The growth of the "big-three" DAMPs has been the largest driver of this winner-take-all concentration, with their direct contribution shown by the difference between black and grey bars in Fig. 9. BlackRock is headquartered in New York, while State Street and Vanguard are headquartered in the second and third largest US asset management centers, Boston and Philadelphia. The latter has enjoyed exceptionally rapid growth attributable to Vanguard (Fig. 10); a particularly interesting case which underscores that costs can be reduced by simply moving to the suburbs (Malvern, PA), while remaining within a leading financial agglomeration. Notably, although the growth of the "big-three" DAMPs explains much of the overall geographic concentration tendency, there is still a large underlying concentration trend even when the growth of the big-three is removed (grey bars in Fig. 9).

\section{The geography of DAMPs II: Regulation and nationality}

Intriguingly, these results suggest that technological disruption is mostly reinforcing rather than challenging the status quo geography of asset management. However, the analysis in Section 6 has two limitations. Firstly, it does not account for the potential for city-level trends to be driven by national-level processes. Secondly, it does not account for intra-firm organizational trends; particularly the possibility that incumbent centers might be hollowed-out functionally (e.g. in tech-related employment) even while consolidating their position as command-and-control centers. In this and the following section we address these two issues.

Notably, in contrast to digital platforms outside of finance-wherein

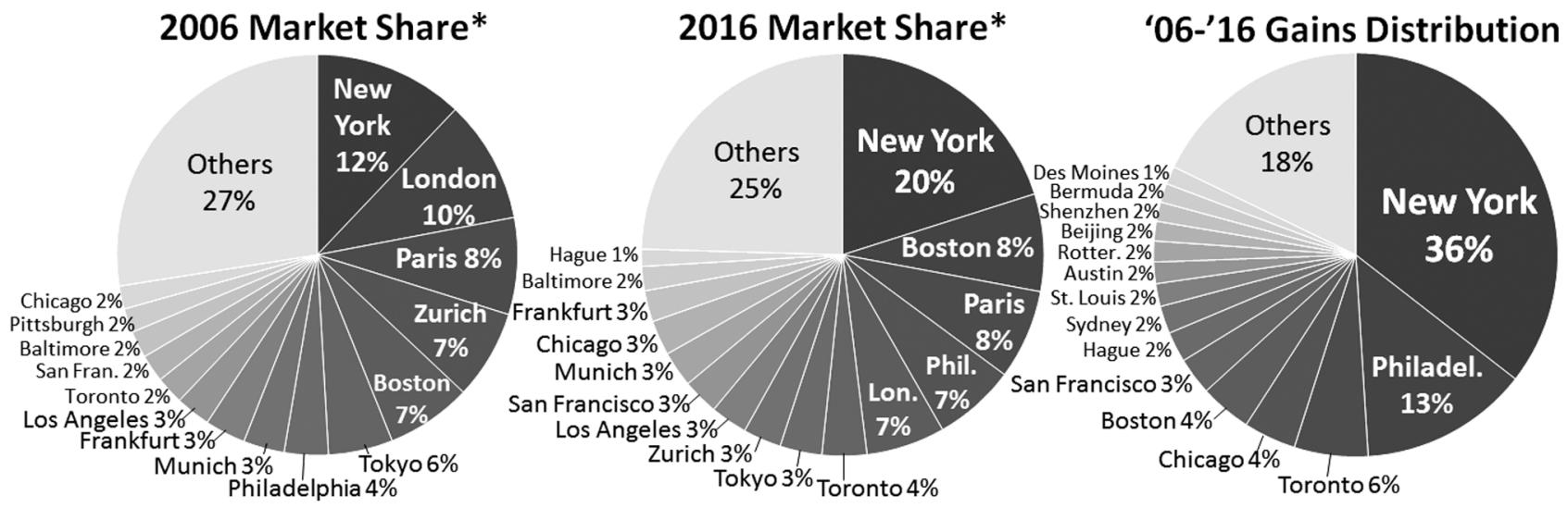

*\% of AUM of top-500 AM firms worldwide, accounted for by firms with HQ in metro area

Source: Authors' calculations based on Willis and Towers Watson, and Bloomberg.com

Fig. 10. 2006-2016 Change in Worldwide Asset Manager Market Share by Headquarters City. 

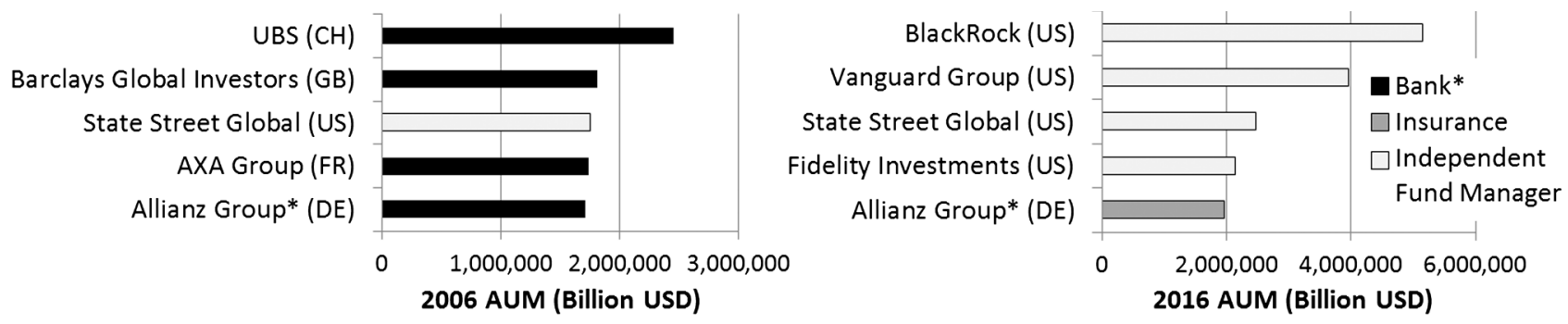

*Group defined as a "bank" for regulatory purposes if it includes a banking subsidiary. Allianz classified as bank in 2006 due to ownership of Dresdner Bank (sold to Commerzbank in 2008)

Source: Towers Watson

Fig. 11. Top-5 World Asset Managers in 2006 and 2016.

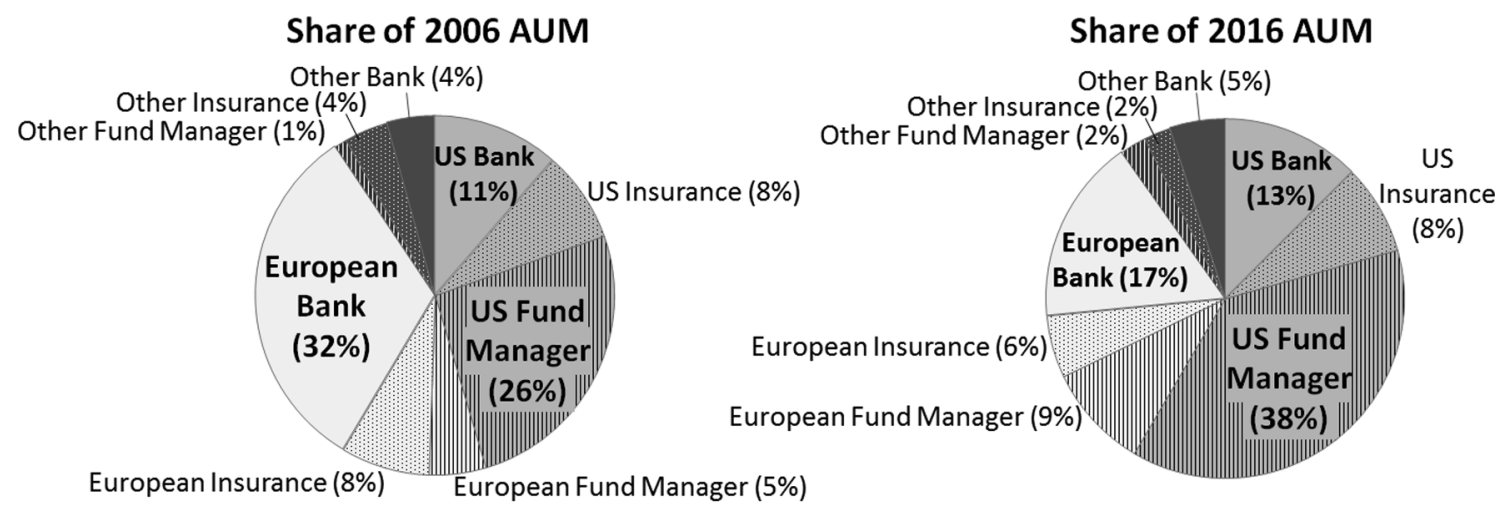

Source: Authors' calculations based on Willis and Towers Watson, and Bloomberg.com

Fig. 12. Asset Management Market Shares by Manager Type, 2006 \& 2016.

competitiveness is often directly linked to technologically-enabled regulatory arbitrage-DAMP business models do not seem to be premised on undercutting regulation. To be fair, many have run into regulatory barriers; when ETFs were first proposed they were incompatible with the Investment Company Act, and could not be implemented until lobbying convinced the SEC to change the relevant rules (Hill et al., 2015). However, where regulatory avoidance itself is the objective, financial firms have always had more attractive tools at their disposal (e.g. pre-crisis shadow banking). In fact, in the context of post-crisis regulatory tightening, index funds seem to have gained competitive advantage not from their ability to circumvent tightened regulation, but rather their ability to leverage economies of scale to comply with it at a lower unit cost (per-AUM) than active funds.

This does not mean that post-crisis regulatory restructuring has not impacted asset management, but rather that these impacts have (with the exception of the point above) been more or less the same for DAMPs and traditional asset managers. As shown in Figs. 11 and 12, the most important trend has been a shift from pre-financial crisis dominance of European banks, to post-crisis dominance of American independent fund managers. Ironically, the rapid pre-crisis growth of European bank securities activities appears to have been partly a product of the paradigm of consolidated supervision established by Basel, which shifted regulatory primacy to bank home states Following Glass Steagall's repeal, this encouraged the acquisition of American securities firms by European banking conglomerates with even weaker home capital supervision than American banks-and above all by British and Swiss "offshore national champion" banks (Haberly and Wójcik, 2018). As shown in Fig. 11, four of the world's top-5 asset managers in 2006 were European banks. Largest was UBS, which owned three of what had been the top-20 American investment banks in the 1980s (Haberly and Wójcik, 2018); \#2 was Barclays, which owed its size to its ownership of Wells Fargo's former index fund division.

Since the crisis this pattern has been reversed, with independent US fund managers holding four of the top-5 asset manager spots in 2016, and banks entirely absent from the top-5 (Figs. 11 and 12). Sprawling European national champion banks were ultimately too large relative to their home economies to be decisively recapitalized by home governments in the wake of the crisis (Haberly and Wójcik, 2018). Consequently, they were forced to restore themselves to health through asset sales-including of asset management arms-with British and Swiss "offshore national champions" undergoing the largest downsizing (Figs. 10 and 11). Basel III's supplementary capital requirements for "Systemically Important Financial Institutions" (SIFIs) have accelerated bank divestments of non-core operations, including asset management arms. Notably, assets under management, as opposed to an institution's own balance sheet, are excluded from SIFI criteria-with lobbying by BlackRock reportedly playing a role in this exclusion (Tracy and Krouse, 2016)—allowing independent asset managers to retain a relatively lean regulatory footprint compared to other large financial firms.

In practice, most divested bank assets have been purchased by American independent fund managers (Fig. 12)—mostly as a path-dependent result of there being more American than European independent fund managers to begin with (due the historical dominance of universal banks in Europe). Banks have also spun-off asset management divisions as standalone managers, with BlackRock as it currently exists emerging out of both trajectories of restructuring. From 1995, BlackRock operated as a subsidiary of PNC Financial, before becoming jointly owned by PNC and Merrill Lynch following its purchase of Merrill Lynch's asset management arm. In 2009, BlackRock became the world's largest fund manager when a distressed Barclays sold it its index fund and ETF operation (taking a stake in BlackRock in the process). Ultimately, all of these bank stakes in BlackRock were divested (apart from a minority PNC stake), leaving it as an independent manager. 


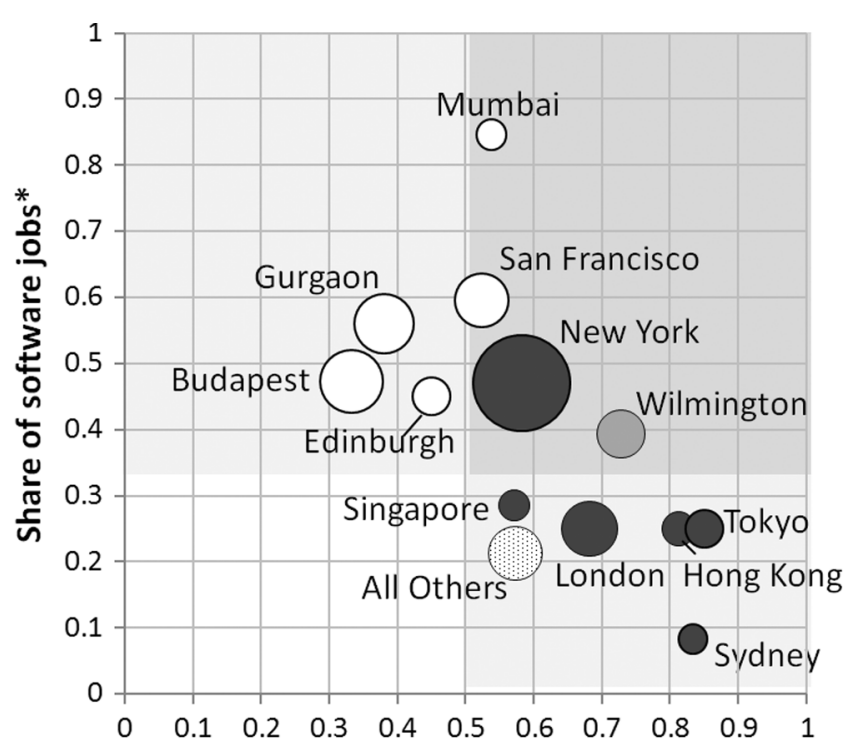

Share of relational and upper-managerial jobs**
Circle area indicates total number of job openings

(497 total on April 27 2018)

iShares listed subsidiary to job

on exchange ratio $>1$

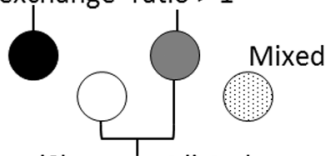

iShares not listed on exchange

*share of jobs returned in search for keywords "software,

engineer, java, or scientist"

** share of jobs returned in

search for keywords

"relationship or president"

Source: blackrock.jobs

(April 27, 2018)

Fig. 13. BlackRock Job Openings by City and Type, April 2018.

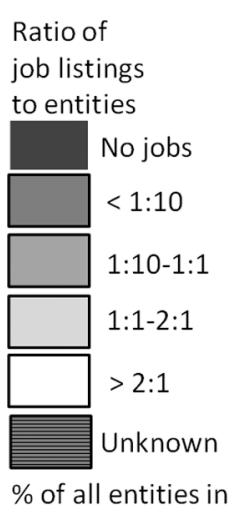

Parentheses (as of early 2018)

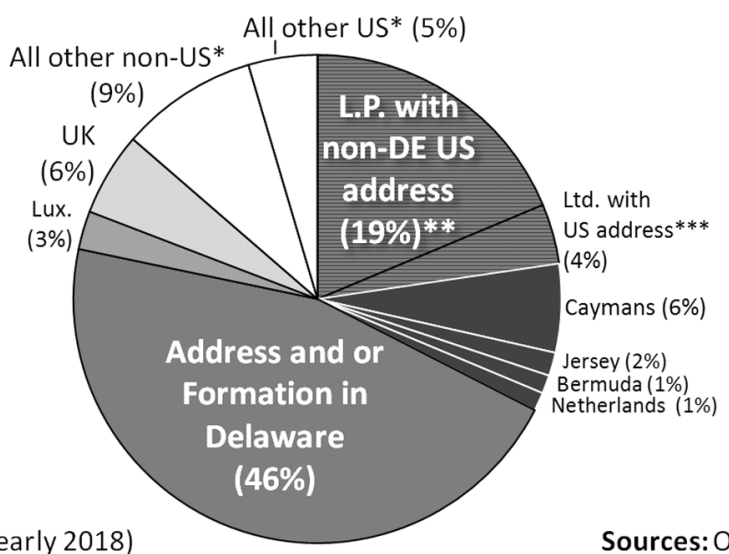

Sources: Orbis and OpenCorporates
* Shading based on collective average for category **L.P. ambiguously indicates either Delaware, UK or nonUS offshore jurisdiction (uncertain job/entity ratio indicated by hashing) ***Ltd. indicates entity formation in non-jurisdiction - typically UK or Cayman ratio indicated by hashing) entity formation in (usually) Islands (uncertain job/entity

Fig. 14. BlackRock internal structure by jurisdiction (entity counts), early 2018.

\section{The geography of DAMPs III: Functional specialization and diversification in the Global Financial Network-the case of BlackRock}

What is intriguing about this musical chairs of asset manager parentage is that it has little bearing on the functional structure of DAMPs-the original San Francisco-based index fund operation that McQuown established at Wells Fargo in the 1970s, for example, has remained the market leader whether owned by Barclays or BlackRock. Like the finding that the rise of DAMPs has consolidated rather than challenged the position of the largest incumbent financial centers, the paramount importance of regulation in pre- and post-crisis asset manager parentage shifts suggests that the geography of DAMP commandand-control overwhelmingly reflects their identity as financial firms, rather than their identity as technology firms. However, this raises the question of how the latter identity is reflected in their geography. In the remainder of the paper, we shed light on this by mapping the world's largest fund manager, BlackRock, through the lens of the Global Financial Network framework outlined in Section 3.

In theory, a financial firm could keep one foot in a headquarters location for regulatory and other reasons, even while (as detailed in Section 3) redistributing the bulk of its activities centrifugally to specialized "paper" offshore centers, "virtual" data centers, "back-office technology centers," and front-office "regional market centers." As we will show, BlackRock's organization partially reflects such a logic; however, there are also powerful agglomerative effects within and between the different functional spheres in Fig. 1, that keep centrifugal unbundling tendencies in check.

Fig. 13 provides an overview of BlackRock's geography based on keyword analysis of all 497 job openings on BlackRock's website on April 27, 2018, the domiciles of all BlackRock entities recorded in Orbis (also see Fig. 14), and the listing exchanges of BlackRock's iShares family of ETFs. City circle areas represent total job openings, while X-and Y-axis positioning shows job role mixture. ${ }^{3} \mathrm{Y}$-axis positioning shows the percentage of jobs associated with software-linked keywords (software, engineer, scientist, or java); X-axis position shows the percentage of jobs associated with relational and upper-managerial keywords ("relationship" or "president"). Circle shading indicates whether any iShares ETFs are listed on a city's exchanges (black), whether there are anomalously numerous BlackRock entities compared to employment (grey), or whether neither of these conditions is met (white).

BlackRock's employment underscores that it is as much a technology as a financial firm, with $42 \%$ of job listings software-related.

\footnotetext{
${ }^{3}$ Keyword search lists were refined experimentally to avoid false positives.
} 
Furthermore, aspects of its organization clearly reflect a technologyenabled logic of centrifugal geographic specialization and dispersion. Two back-office technology centers-Budapest and Gurgaon-account for $26 \%$ of software job listings. Edinburgh (with lower costs than London) also appears to serve as a back-office technology center. This pattern supports Tett's (2018) argument that US asset managers are cutting costs by moving jobs to low-cost locales, even while questioning the assumption that these must be US locales. Furthermore, BlackRock's "brain," Aladdin, is not housed in a stock exchange co-location center, but rather a server farm in Wenatchee, Washington, between two hydroelectric dams. Finally, BlackRock's "paper" geography corresponds tenuously to employment, with Delaware and other offshore jurisdictions of hugely disproportionate importance (Fig. 14).

However, BlackRock also shows countervailing tendencies towards geographic centralization and functional diversification. BlackRock's largest high-tech employment center is Manhattan, which has more software job openings than Gurgaon and Budapest combined, and is where BlackRock Solutions, which includes Aladdin, is based. BlackRock's largest US offices-New York, San Francisco, and Wilmington, Delaware-also have strikingly diversified mixtures of software-intensive and "conventional" financial center functions. This is congruent with what can be dubbed the "cyborg" investment management approach of BlackRock. As the head of BlackRock Solutions puts it: "human plus computer' will always lead to a better result than computer alone or a human alone" (Segal, 2016). This philosophy is most important in active management, in which—notwithstanding its much larger passive AUM-BlackRock has the world's second largest market share (Fig. 6). As CEO Larry Fink described a recent equities team reorganization:

“This wasn't about machines replacing human beings. Some of our large-cap products, our core alpha products, were underperforming, but our quant equity teams were doing quite well...They were looking at different insights. We wanted a much more holistic platform where the fundamental teams can work with the model people. They see things that the model people do not see, and more importantly we wanted to have the output of the models going to some of the fundamental people. Cross-fertilization, no different from what we do in fixed income...We have a venture...in AI, a whole group of people working on developing computer-based investing. And that's truly a computer saying, "Buy this. Sell that." [But] We're not there yet...there's no true AI yet in investing" (Schatzker, 2017).

Particularly intriguing is the apparent functional convergence between BlackRock's New York and San Francisco offices (the latter built around Wells Fargo's pioneering index fund operation inherited via Barclays). Beyond the technological intensity of operations in New York, this entails a growing importance of San Francisco-based relational functions. Both BlackRock's corporate governance office and regional head-for-the-Americas are based in San Francisco. Interestingly, this appears to largely reflect the extent to which the regional growth of both tech firms, and reservoirs of investible capital (including the two largest US pension funds in Sacramento), are driving conventional relational financial center agglomeration. According to CEO Larry Fink, the head of Americas' move to San Francisco was motivated by both the "critical importance to BlackRock of tapping into innovation on the west coast," and the fact that "the region is home to many of our largest clients" (Smith, 2017).

Notwithstanding this convergence, however, the New York securities market poses a daunting barrier to any pretensions of San Francisco to become the US financial capital. As detailed by Wójcik (2011), exchange platform virtualization has overwhelmingly promoted a concentration rather than diffusion of both the technical and human geographies of the securities market. In the US, nearly all regional exchanges have been absorbed by New York, with most of the US securities market now located, in a literal sense, in the NYSE Liquidity
Center in the New York suburb of Mahwah, NJ. Notably, this contains what remains of the formerly San Francisco-based Pacific Stock Exchange, which pioneered many areas of online exchange platform development. This is consolidated into the NYSE Arca platform, on which most US ETFs (including BlackRock's) are listed. BlackRock's international employment is also, with the exception of technology-oriented back-offices, concentrated in dominant regional exchange hubs-most importantly London, Tokyo, Hong Kong, Singapore and Sydney. The distribution of employment among these sites is itself extremely polarized, with London accounting for $42 \%$ of the total. London accounts for $77 \%$ of BlackRock's European job openings outside of the back-office technology centers of Budapest and Edinburgh, suggesting that virtually all of its European relational and trading activities are concentrated here.

Another parallel between BlackRock's US and international organization is the entanglement of "paper" and "real" operational geographies. A securities market is not simply an informational, but also a contractual and regulatory nexus-as such, the distribution of entities in Fig. 14 does not fully capture the importance of the major exchange hubs to BlackRock's "paper" geography. London, Singapore, and Hong Kong, in particular, have built their positions as financial centers on legal-regulatory foundations, particularly by bridging the divide between "onshore" institutional reputation and "offshore" institutional flexibility. Notably, BlackRock's largest incorporation hub, Delaware, appears to be following a similar developmental trajectory. Wilmington is BlackRock's third largest US hiring site, with a diversified mix of technical and relational-managerial jobs.

\section{Conclusion}

On August 2, 2018, asset manager shares plunged following an announcement by the world's largest active fund manager-Bostonbased Fidelity-that it would be one-upping the traditional low-cost passive leaders by offering the first zero-fee index funds. Even while "taking the democratization of investing to a whole new level" (Bernard, 2018), this final evolution of asset management into a free service, provided through cross-subsidized platforms, is expected to intensify an already-ongoing industry shake-out and consolidation (Kaisser, 2018).

The evidence in this paper underscores the scale of this technologydriven upheaval; however, it also suggests that the identity and geography of digital asset management platform providers has remained, to a rather counterintuitive extent, aligned with their identity as financial firms rather than as technology firms. Indeed, by focusing on the potential for finance to be disrupted from the outside by tech startups, many contemporary commentaries appear to have underestimated the extent to which the industry is already being transformed from within. Notably, the San Francisco Bay Area has been a key locus of technological innovation in asset management for decades, from the development of index funds in the 1970s, to the expansion of ETFs in the 90s; however, the most important actors in this innovation have been major multinational banks and fund managers. Furthermore, while Bay Area startups have recently spearheaded the development of robo-advising, these pioneers are increasingly being either outcompeted or purchased by established financial giants. Perhaps most strikingly, from a geographic standpoint it is the leading incumbent asset management centers of the US Northeast-and above all New York-which have been the largest beneficiaries of the tendency towards technology-enabled winner-take-all industry consolidation.

To a large extent, this continuity appears to reflect the fact that both the informational intensity, and regulatory and organizational fluidity of the digital platform model are more evolutionary than revolutionary in finance. What appears to be particularly important, is that financial innovation has always been entangled in a labyrinth of "paper" legal, regulatory, and, broadly speaking, political dimensions. Notwithstanding their unflappable willingness to spearhead not only 
technological, but also regulatory disruption in other industries, the major Silicon Valley tech giants appear to be rather out of their depth in this context. Indeed, with the exception of payments, these firms have mostly been too intimidated by the regulatory complexities of finance to attempt to enter the sector. Facebook may now be breaking with this pattern with its foray into cryptocurrencies. However, its ham-handed approach to dealing with regulators-despite needing to navigate a minefield of digital privacy and financial regulatory issues spanning numerous countries (Kharif, 2019)—suggests that the very culture of disruption that underpins the success of Silicon Valley tech firms may paradoxically hinder their ability to disrupt financial services. This makes them poorly placed to compete with financial firms who have no such problems adopting technological innovations, including by directly internalizing control over Silicon Valley offices and start-ups.

Entry into finance, it seems, threatens to exacerbate the already severe tension between the traditional culture of innovation of tech firms, and the growing political pressure on digital platform providers to evolve into a role with which financial firms have long been familiar; i.e. that of state-supervised utilities who can at most use subtle and roundabout strategies to subvert this supervision. Notably, the most successful digital asset management platform providers have an even more utility-like character than most financial firms; as reflected in their shallow depth of value extraction compared to breadth of financial market footprint, ${ }^{4}$ lack of aggressive regulatory arbitrage, and corporate identities that openly promote "boringness" (see Wee, 2012). Indeed, BlackRock's role in the TARP program entailed it acting as more or less an extension of the Federal Reserve (Lipton and Merced, 2009). Meanwhile, in the one country where technology giants (e.g. Alibaba) have achieved a central position in finance-China-their success seems to be directly linked to their wholehearted adoption of a role as appendages of Lessig's (2006) digital "sovereigns of everywhere" (Jia and Kenny, 2016; Töpfer, 2018).

Most notably, the geography of the world's leading financial centers has, for centuries, been perhaps the single most stable and slowlychanging layer of the world's economic geography (Arrighi, 1994). Given the tremendous technological upheavals that have already occurred over this period, there is reason to expect that this geographic stability will persist.

\section{Acknowledgements}

This research in this paper was presented under the title "Asset Management as a Digital Platform Industry: A Global Financial Network Perspective" at the 2018 Global Conference on Economic Geography in Cologne, the 2018 Conference of the Forum for Macroeconomics and Management Policies in Berlin, and the 2019 Society for the Advancement of Socio-Economics conference in New York. We would like to thank the other participants of these conferences, as well as Jacques de Saussure and two anonymous reviewers, for their helpful comments. Any errors or omissions are solely the responsibility of the authors.

The project has received funding from the European Research Council (ERC) under the European Union's Horizon 2020 research and innovation programme (grant agreement number 681337). The article reflects only the authors' views and the ERC is not responsible for any use that may be made of the information it contains.

\section{Declaration of Competing Interest}

None.

\footnotetext{
${ }^{4}$ BlackRock only has one fifth of JP Morgan's and one twelfth of Google's market capitalization. Vanguard, meanwhile, has a mutual ownership structure that effectively makes it an investor cooperative.
}

\section{References}

Acquier, A., Daudigeos, T., Pinske, J., 2017. Promises and paradoxes of the sharing economy: an organizing framework. Technol. Forecast. Social Change 125, 1-10.

Arner, D.W., Barberis, J., Buckley, R.P., 2016. The evolution of fintech: a new post-Crisis Paradigm? Georgetown J. Int. Law 47 (4), 1345-1393.

Arrighi, G., 1994. The Long Twentieth Century: Money, Power, and the Origin of Our Time. Verso, New York.

Bernard, T.S., 2018. Fidelity Tries Luring Investors with Two New No-Fee Funds. So What's The catch? The New York Times. Aug. 10. https://www.nytimes.com/2018/ 08/10/business/fidelity-mutual-funds-fees.html.

Bernstein, P.L., 2005. Capital Ideas: The Improbable Origins of Modern Wall Street. John Wiley and Sons, Hoboken.

Betz, F., 2016. Models of financial markets, Asian Bus. Res, 1 (2), 30-45.

BlackRoc, 2018. Aladdin Platform Overview. https://www.blackrock.com/aladdin/ offerings/aladdin-overview (accessed Aug. 14 2018).

Clark, P., Buhayar, M., 2018. Wall Street Slaps Down NYC Again with AllianceBernstein's Move to Nashville. Bloomberg. May 2. https://www.bloomberg.com/news/articles/ 2018-05-02/alliancebernstein-chooses-nashville-in-wall-street-rebuke-of-nyc.

Coe, N.M., Lai, K.P.Y., Wójcik, D., 2014. Integrating finance into global production networks. Regional Stud. 48 (5), 761-777.

Cook, G.S., Pandit, N.R., Beaverstock, J.V., Taylor, P.J., Pain, K., 2007. The role of location in knowledge creation and diffusion: evidence of centripetal and centrifugal forces in the City of London financial services agglomeration. Environ. Plan. A 39 (6), 1325-1345.

Crigger, L., 2017. A Tour of the Top 10 Robos. ETF.com. Jan. 24. http://www.etf.com/ publications/etfr/tour-top-10-robos?nopaging $=1$ (accessed Aug. 14 2018).

Davies, A.R., Donald, B., Gray, M., Knox-Hayes, J., 2017. Sharing economies: moving beyond binaries in a digital age. Cambridge J. Regions, Econ. Soc. 10 (2), 209-230.

D'Hulster, K., 2012. Cross border banking supervision: incentive conflicts in supervisory information sharing between home and host supervisors. J. Banking Regulat. 13 (4), 300.

Dimon, J., 2014. Chairman and CEO Letter to Shareholders (JP Morgan Chase \& Co. 2014 Annual Report). https://www.jpmorganchase.com/corporate/annual-report/2014/ ar-introduction.htm.

Dixon, A., Monk, A.H.B.A., 2014. Frontier finance. Ann. Assoc. Am. Geogr. 104 (4), $852-868$.

Economist, 2013a. Onshore Financial Centers: Not a Palm Tree in Sight. The Economist. Feb. 16. https://www.economist.com/special-report/2013/02/16/not-a-palm-treein-sight.

Economist, 2013b. The Monolith and the Markets. The Economist. Dec. 7 2013. https:// www.economist.com/briefing/2013/12/07/the-monolith-and-the-markets.

Economist, 2017. The Investment-Management Industry Faces a Big Squeeze. The Economist. May 11. https://www.economist.com/finance-and-economics/2017/05/ 11/the-investment-management-industry-faces-a-big-squeeze.

Economist, 2018a. Raiders of the Killer App. The Economist. June 30.

Economist, 2018b. Special Report: Fixing the Internet. The Economist. June 30

Economist, 2018c. More Knock-On than Network. The Economist. June 30.

Economist, 2018d. A New School in Chicago. The Economist. June 30.

Edelman, B.G., Geradin, D., 2015. Efficiencies and regulatory shortcuts: how should we regulate companies like AirBNB and Uber? Stanford Technol. Law Rev. 19 (2), 293.

Ellis, C.D. 1975. The loser's game. Financial Anal. J. July/August, 19-26.

Evans, P.C., Gawer, A., 2016. The rise of the platform enterprise: a global survey. Center for Global Enterprise, Emerging Global Platform Series, January 2016.

Fama, E.F., 1995. Random walks in stock market prices. Financial Anal. J. 51 (1), 75-80.

Ferri, P., Minsky, H., 1992. Market processes and thwarting systems. Struct. Change Econ. Dyn. 3 (1), 79-91.

Fichtner, J., Heemskerk, E.M., Garcia-Bernardo, J., 2017. Hidden power of the Big Three? Passive index funds, re-concentration of corporate ownership, and new financial risk. Bus. Politics 19 (2), 298-326.

Flichy, P., 1993. The birth of long distance communication: semaphore telegraphs in Europe (1790-1840). Réseaux: French J. Commun. 1 (1), 81-101.

Frey, C.B., Osborne, M.A., 2017. The future of employment: how susceptible are jobs to computerisation? Technol. Forecast. Social Change 114, 254-280.

Fumagalli, A., Lucarelli, S., Musolino, E., Rocchi, G., 2018. Digital labour in the platform economy: the case of Facebook. Sustainability 10 (6), 1757.

Gach, R., Gotsch, M., 2016. Fintech's golden age. Fintech Innovation Lab Report. http:// pfnyc.org/wp-content/uploads/2017/04/Fintech-Golden-Age_2016-06.pdf.

Gara, A., 2017. BlackRock's Edge: Why Technology is Creating the Amazon Of Wall Street. Forbes. Dec. 26. https://www.forbes.com/sites/antoinegara/2017/12/19/ blackrocks-edge-why-technology-is-creating-a-6-trillion-amazon-of-wall-street/\# $5881 \mathrm{~b} 6 \mathrm{c} 2561 \mathrm{~b}$.

Haberly, D., Wójcik, D, 2017a. Culprits or bystanders? Offshore jurisdictions and the global financial crisis. J. Financial Regulat. 2 (1), 233-261.

Haberly, D., Wójcik, D., 2017b. Earth incorporated: centralization and variegation in the global company network. Econ. Geogr. 93 (3), 241-266.

Haberly, D., Wójcik, D., 2018. The end of the great Inversion: offshore national champion banks and the global financial crisis. Working Paper. https://papers.ssrn.com/sol3/ papers.cfm?abstract_id $=3280497$.

Hall, S., 2017. Rethinking international financial centres through the politics of territory: Renminbi internationalisation in London's financial district. Trans. Institute British Geogr. 42 (4), 489-502.

Hill, J.M., Nadig, D., Hougan, M., 2015. A comprehensive guide to exchange traded funds (ETFs). CFA Institute Research Foundation. http://www.cetfa.ca/files/1433184781 CFA\%20-\%20ETF\%20Report.pdf. 
Jaeger, P.T., Lin, J., Grimes, J.M., Simmons, S.N., 2009. Where is the cloud? Geography, economics, environment, and jurisdiction in cloud computing. First Monday 14 (5).

Jessop, S., Hunnicutt, T., 2017. BlackRock Takes Scalable Capital Stake in Europe 'RoboAdvisor' Push. Reuters. June 20. https://www.reuters.com/article/us-blackrockscalablecapital/blackrock-takes-scalable-capital-stake-in-europe-robo-advisor-pushidUSKBN19A322.

Jia, K., Kenney, M., 2016. Mobile internet business models in China: vertical hierarchies, horizontal conglomerates, or business groups? BRIE Working Paper 2016-6. http:// www.brie.berkeley.edu/wp-content/uploads/2015/02/Working-Paper-2016-6. JiaKenney.pdf.

Kahn, J., 2015. Greeting from Bitcoin Island. Bloomberg. Sept. 8. https://www. bloomberg.com/news/features/2015-09-07/isle-of-man-tax-haven-with-tailless-catsbecomes-bitcoin-hub.

Kaisser, N., 2018. Fidelity's No-Fee Funds Unleash the Power of Free. Bloomberg. Aug. 2. https://www.bloomberg.com/view/articles/2018-08-02/fidelity-s-no-fee-fundsunleash-the-power-of-free.

Kenney, M., Zysman, J., 2016. The rise of the platform economy. Issues Sci. Technol. 32 (2), 61-69.

Kaya, O., 2017. Robo-advice - a true innovation in asset management. EU Monitor Global Financial Markets, Deutsche Bank Research. https://www.dbresearch.com/PROD/ RPS_EN-PROD/PROD0000000000449125/Robo-advice_\%E2\%80\%93_a_true_ innovation_in_asset_managemen.pdf.

Kharif, O,. 2019. Why (Almost) Everyone Hates Facebook's Cryptocurrency Libra. Bloomberg. July 16. https://www.bloomberg.com/news/articles/2019-07-16/whyeverybody-almost-hates-facebook-s-digital-coin-quicktake.

Knuth, S., Potts, S., 2015. Legal geographies of finance: editors' introduction. Environ. Plan. A 48 (3), 458-464.

Langley, P., Leyshon, A., 2017. Platform capitalism: the intermediation and capitalisation of digital economic circulation. Finance Soc. 3 (1), 11-31.

Lessig, L., 2006. Code, Version 2.0. Basic Books, New York.

Lipton, E., Merced, M.J., 2009. Wall St. Firm Draws Scrutiny as US Adviser. The New York Times. May 18. https://www.nytimes.com/2009/05/19/business/19blackrock.html.

Malkiel, B., 2013. Asset management fees and the growth of finance. J. Econ. Perspect. 27 (2), 97-108.

Mason, T., 2017. U.S. Digital Adviser Forecast: AUM To Surpass $\$ 450$ B By 2021. S\&P Global Market Intelligence. https://www.spglobal.com/our-insights/US-DigitalAdviser-Forecast-AUM-To-Surpass-450B-By-2021.html.

McLaughlin, T., 2016. Fidelity Gives BlackRock an Early Leg up in Robo Advice Brawl. Reuters. Dec. 16. https://www.reuters.com/article/us-fidelity-blackrock-roboidUSKBN1452BN.

Mooney, 2017. BlackRock Bets on Aladdin as Genie of Growth. Financial Times. May 17. https://www.ft.com/content/eda44658-3592-11e7-99bd-13beb0903fa3.

Neef, D., 2014. Digital Exhaust: What Everyone Should Know About Big Data, Digitization and Digitally Driven Innovation. Pearson FT Press, Upper Saddle River, New Jersey.

Pistor, K., 2013. A legal theory of finance. J. Comp. Econ. 41 (2), 315-330.

Quah, D., 1996. The invisible hand and the weightless economy. Centre for Economic Performance Occasional Paper no. 12. http://eprints.lse.ac.uk/2271/.

Reklaitis, V., 2015. Here's the Advice You Get from Vanguard's New Robot-Human Hybrid. MarketWatch. May 18. https://www.marketwatch.com/story/heres-the- advice-you-get-from-vanguards-new-robot-human-hybrid-2015-05-18.

Roberts, S., 1994. Fictitious capital, fictitious spaces: the geography of offshore financial flows. In: Martin, R., Thrift, N., Corbridge, S. (Eds.), Money, Power and Space. Blackwell, Oxford, pp. 91-115.

Rosenbaum, E., 2018. BlackRock, World's Biggest Investing Company, is Planning to Nickel-and-Dime You. CNBC. May 9. https://www.cnbc.com/2018/05/09/ blackrock-is-developing-tools-to-spur-millennial-and-gen-z-investing.html.

Schatzker, E., 2017. Larry Fink Q\&A. Bloomberg. April 18. https://www.bloomberg.com/ features/2017-blackrock-larry-fink-interview/.

Segal, J., 2016. BlackRock is Making Big Data Bigger. Institutional Investor. Nov. 1. https://www.institutionalinvestor.com/article/b14z9p1z99mmlg/blackrock-ismaking-big-data-bigger.

Smith, 2017. BlackRock Pivots to US West Coast as Part of Tech Push. The Financial Times. Nov. 5. https://www.ft.com/content/a1393e7c-c0ac-11e7-b8a3$38 \mathrm{a} 6 \mathrm{e} 068 \mathrm{f} 464$.

S\&P Global, 2017. SPIVA US Scorecard, year-end 2016. https://us.spindices.com/ documents/spiva/spiva-us-year-end-2016.pdf.

Sushko, V., Turner, G., 2018. The implications of passive investing for securities markets. BIS Quart. Rev. (March), 113-131.

Swan, M., 2015. BlockChain: Blueprint for a New Economy. O'Reilly Media, Sebastopol CA.

Tett, G., 2018. AllianceBernstein's Nashville Move Threatens New York and London. Digital Disruption Makes it Easier for Financial Companies to Relocate. Financial Times. 3 May. https://www.ft.com/content/e483a6ea-4e23-11e8-9471a083af05aea7.

Tobin, J., 1984. On the efficiency of the financial system. Lloyds Bank Rev. 153, 1-15.

Töpfer, L., 2018. Inside the global financial network: the state, lead-firms, and the rise of fintech. Dialogues Human Geogr. 8 (3), 294-299.

Tracy, R., Krouse, S., 2016. One firm getting what it wants in Washington: BlackRock. Wall Street J. April 20. https://www.wsj.com/articles/one-firm-getting-what-itwants-in-washington-blackrock-1461162812.

Urban, M., 2018. Producing investment returns at the margin of finance: a frontier talent proposition. Geoforum 95, 102-111.

Wee, G., 2012. Frankly Fink: How 'Boring' Built the World's Largest Asset Manager. The Washington Post. Sept. 30.

Willmer, S., Kumar, N., 2017. Why Google and Amazon Keep Fidelity and BlackRock Up at Night. Bloomberg. Dec. 13. https://www.bloomberg.com/news/features/2017-1213/hey-google-am-i-diversified-why-fidelity-fears-silicon-valley.

Wójcik, D., 2011. The Global Stock Market: Issuers, Investors, and Intermediaries in an Uneven World. Oxford University Press, Oxford.

Wójcik, D., 2012. The end of investment bank capitalism? An economic geography of financial jobs and power. Econ. Geogr. 88 (4), 345-368.

Wójcik, D., 2018. Rethinking global financial networks: China, politics, and complexity. Dialogues Human Geogr. 8 (3), 272-275.

Wójcik, D., Camilleri, J., 2015. 'Capitalist tools in socialist hands?' China Mobile in global financial networks. Trans. Inst. British Geogr. 40 (4), 464-478.

Zook, M., Grote, M.H., 2017. The microgeographies of global finance: high-frequency trading and the construction of information inequality. Environment and Planning A 49 (1), 121-140. 